\title{
Genetic Diversity Estimates of Santalum album L. through Microsatellite Markers: Implications on Conservation
}

\author{
Tanzeem Fatima ${ }^{*}$, Ashutosh Srivastava ${ }^{1}$, Vageeshbabu S. Hanur ${ }^{2}$, P. V. Somashekar ${ }^{1}$, \\ M. Srinivasa Rao ${ }^{3}$ \\ ${ }^{1}$ Genetics and Tree Improvement Division, Institute of Wood Science and Technology, Bangalore, India \\ ${ }^{2}$ Division of Biotechnology, Indian Institute of Horticultural Research, Bangalore, India \\ ${ }^{3}$ Woodworking Division, Institute of Wood Science and Technology, Bangalore, India \\ Email: ^tanzeem.fatima@gmail.com
}

How to cite this paper: Fatima, T., Srivastava, A., Hanur, V.S., Somashekar, P.V. and Srinivasa Rao, M. (2019) Genetic Diversity Estimates of Santalum album L. through Microsatellite Markers: Implications on Conservation. American Journal of Plant Sciences, 10, 462-485.

https://doi.org/10.4236/ajps.2019.103033

Received: January 17, 2019

Accepted: March 18, 2019

Published: March 21, 2019

Copyright $\odot 2019$ by author(s) and Scientific Research Publishing Inc. This work is licensed under the Creative Commons Attribution International License (CC BY 4.0).

http://creativecommons.org/licenses/by/4.0/

\begin{abstract}
Sandalwood (Santalum album L.) is the second most expensive wood in the world. There are approximately 16 species of sandalwood (S. album, S. spicatum, $S$. austrocaledonicum, $S$. yasi, $S$. lanceolatum, S. ellipticum, S. macgregorii, $S$. insulare) occurring naturally throughout Australia, India, Indonesia, Papua New Guinea and the islands of the South Pacific. In India, S. album is found all over the country, with over $90 \%$ of the area in Karnataka, Tamil Nadu, Kerala, Andhra Pradesh and Telangana state. It is highly economic tropical tree species because of its scented heartwood and heartwood oil. Several causes have been attributed to the depletion of sandalwood population mainly amongst which theft is causing negative effect on the quality of species by constant removal of superior clones. The aim of this study was to determine the genetic diversity of $S$. album. For this, 177 genotypes of $S$. album from 14 populations of three states (Karnataka, Telangana state and Kerala) in southern India were selected. The genetic diversity and genetic structure were characterized through 25 SSR markers developed by cross amplification of different species of Sandalwood. Under this study, following genetic diversity parameters were estimated at individual level and population level; Number of alleles $(\mathrm{Na}) 9.107$, Effective number of alleles $(\mathrm{Ne}) 7.56$, Observed heterozygosity (Ho) 0.187 , Expected heterozygosity (He) 0.861 , Shannon information index (I) 2.03, F statistics 0.89, Polymorphic information content (PIC) 0.87 and Gene flow (Nm) 4.98. The estimates of gene flow among the populations of Kodada Telangana $(\mathrm{Nm}=15.109)$; IWST Karnataka $(\mathrm{Nm}=$ 13.62) than across other geographical populations $(\mathrm{Nm}=9.40)$. Analysis of molecular variance (AMOVA) revealed that $3 \%$ of the total variation was due
\end{abstract}


to differences among populations and $97 \%$ due to differences within the populations. The genetic differentiation among populations $\left(\mathrm{F}_{\mathrm{ST}}\right) 0.012$ at $\mathrm{p}<$ 0.001 was significant. Structure clustering at Ks $=3$ highlighted three distinct groups with the inferred clusters i. 0.369 , ii. 0.304 , iii. 0.327. Structure analysis revealed that genetic structure of Kerala and Karnataka and Telangana populations were admixtures and classified in three groups. In addition, all the accessions were clearly divided into three major clusters by UPGMA dendrogram which could be further divided into five sub groups. Principal component analysis (PCA) results showed the combined variation $82.2 \%$ of these markers. This study highlights the knowledge of genetic variation in sandalwood across the herd population of sandalwood in India. The highest range of polymorphism was detected with SSR markers developed from Osyris lanceolata compared to Santalum. austrocaledonicum, Santalum. insulare and Santalum. spicatum. This study would help in conservation of the Sandalwood populations with high profile of genetic diversity and selection of clones for genetic improvement program.

\section{Keywords}

Sandalwood, Genetic Diversity, Alleles, Microsatellite Markers, PCA

\section{Introduction}

Santalum album L. is medium sized evergreen hemi-parasitic economically important aromatic tree species. The genus Santalum belonging to the family Santalaceae, which consist of 15 species ( $S$. album, S. spicatum, S. austrocaledonicum, $S$. yasi, $S$. lanceolatum, $S$. ellipticum, $S$. macgregorii, $S$. insulare) occurring naturally throughout Australia, India, Indonesia, Papua New Guinea and the islands of the South Pacific. In India, S. album is found all over the country, with over $90 \%$ of the area in Karnataka, Tamil Nadu, Kerala, Andhra Pradesh and Telangana state. Sandalwood has been categorized as "vulnerable" by International Union for Conservation of natural and natural resources [1] Indigenous to peninsular India, its natural distribution estimation, estimated at about 9600 $\mathrm{km}^{2}$ is confined predominantly to the two states of Karnataka $\left(500 \mathrm{~km}^{2}\right)$ and Tamil Nadu $\left(3600 \mathrm{~km}^{2}\right)$ [2]. In India it found distributed all over the country with over $90 \%$ of the area in Karnataka, Tamil Nadu, Andhra Pradesh and Kerala. Santalum album is culturally and economically important species for more than fifteen countries [3]. Sandalwood is valued for two important traits, heartwood and essential oil obtained from the heartwood. Both of these are considered to be highly prized and are used in incense, perfumes, medicine and carving [4]. Severe biotic factors including human interference, leading to heavy exploitation and massive clearance, grazing, fire and spike disease have selectively eroded the best trees of sandalwood [5]. Result indicated significant reduction of genetic variability in harvested population. This is causing negative effect on the quality of species by constant removal of superior clones. The aim of this study 
was to determine the genetic diversity of $S$. album. For this, 177 genotypes of $S$. album from 14 populations of three states (Karnataka, Telangana state and Kerala) in southern India were selected. The genetic diversity and genetic structure were characterized through 25 SSR markers developed by cross amplification of different species of Sandalwood. This study highlights the knowledge of genetic variation in sandalwood across the highest range of polymorphism was detected with SSR markers developed from Osyris lanceolata compared to Santalum austrocaledonicum, Santalum insulare and Santalum spicatum.

\section{Materials and methods:}

a) Sample collection: The gentic diversity of the Santalum album was assessed by undertaking survey and sampling along the area of natural populations and plantations from the stretch of 1,162 Km (Telanagana, Karnataka and kerala) in southern part of India Figure 1.

b) Sampling: Total 177 samples representing three distinct states of Southern India were selected (Table 1). To precede the genetic diversity study matured leaves of sandalwood randomly collected from healthy trees based on heartwood content Figure 2 and put it into desiccated silica gel containing zip lock covers to absorb the moisture content. The samples were kept for drying at least 3 to 4 days and then stored the dried samples to $-20^{\circ} \mathrm{C}$ cryogenic freezer to maintain the quality of the leaves for further analysis.

c) Total genomic DNA isolation: Total genomic DNA was extracted from stored silica dried mature leaves of $S$. album L. accessions 177 trees grown in 14

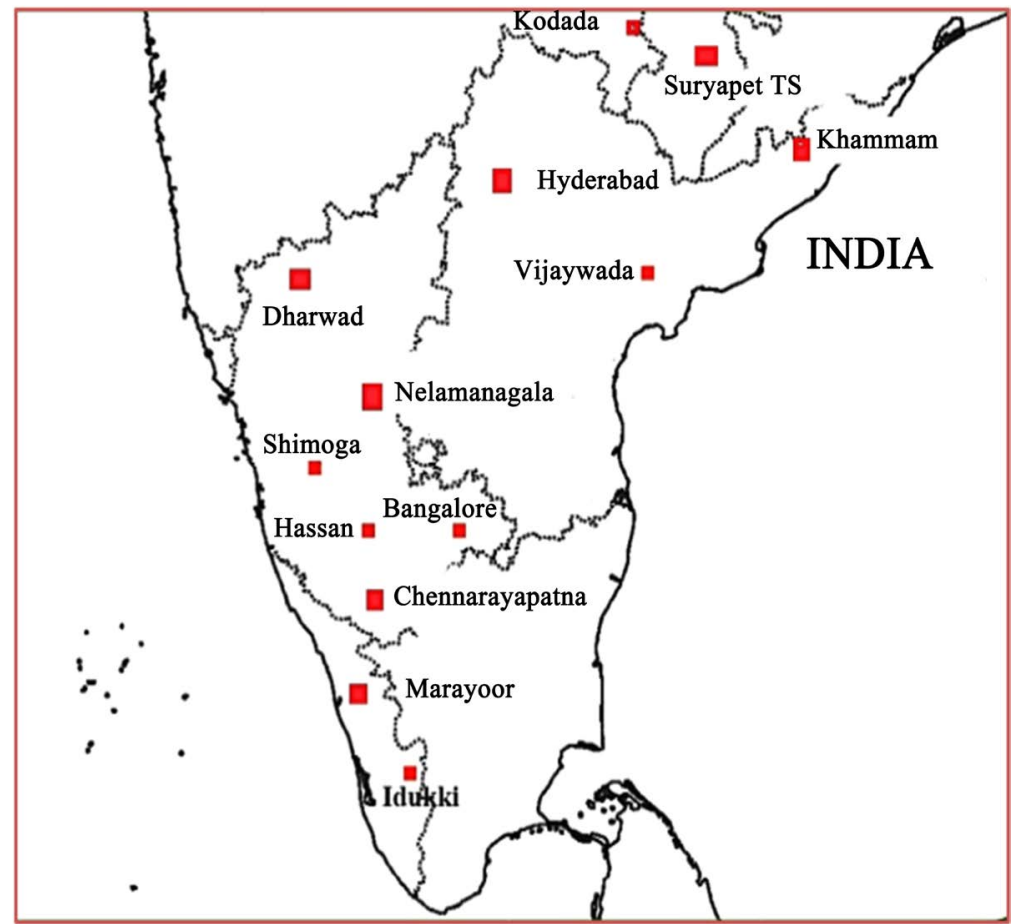

Figure 1. Map of Southern India showing the geographic location of $S$. album sample collection regions in Karnataka, Kerala and Telangana state. 
Table 1. Details of $S$. album samples collected locations in Southern Part of India (Karnataka, Kerala and Telangana state).

\begin{tabular}{|c|c|c|c|c|c|}
\hline Sl No. & Provenances & Latitude $(\mathrm{N})$ & Longitude (E) & Origin & Sample size (N) \\
\hline 1. & Kodada TS & $10^{\circ} 13^{\prime} 22.1^{\prime \prime}$ & $77^{\circ} 09^{\prime} 18.5^{\prime \prime}$ & Plantation & 22 \\
\hline 2. & Suryapet TS & $17^{\circ} 07^{\prime} 36.2^{\prime \prime}$ & $079^{\circ} 50^{\prime} 45.2^{\prime \prime}$ & Plantation & 22 \\
\hline 3. & Khammam TS & $17^{\circ} 13^{\prime} 4.08^{\prime \prime}$ & $79^{\circ} 84^{\prime} 9.01^{\prime \prime}$ & Plantation & 10 \\
\hline 4. & Hyderabad TS & $17^{\circ} 55^{\prime} 05.05^{\prime \prime}$ & $78^{\circ} 44^{\prime} 48.2^{\prime \prime}$ & Plantation & 10 \\
\hline 5. & Marayur $1 \mathrm{KL}$ & $10^{\circ} 14^{\prime} 47.9^{\prime \prime}$ & $77^{\circ} 9^{\prime} 23.4^{\prime \prime}$ & Natural & 12 \\
\hline 6. & Marayur $2 \mathrm{KL}$ & $10^{\circ} 16^{\prime} 39.6^{\prime \prime}$ & $77^{\circ} 09^{\prime} 30.9^{\prime \prime}$ & Natural & 10 \\
\hline 7. & Marayur L3 KL & $10^{\circ} 16^{\prime} 41.3^{\prime \prime}$ & $77^{\circ} 09^{\prime} 27.8^{\prime \prime}$ & Natural & 10 \\
\hline 8. & IWSKA & $13^{\circ} 00^{\prime} 41.3^{\prime \prime}$ & $77^{\circ} 34^{\prime} 17.6^{\prime \prime}$ & Natural & 10 \\
\hline 9. & Nelamangala KA & $13^{\circ} 00^{\prime} 39.9^{\prime \prime}$ & $77^{\circ} 34^{\prime} 14.9^{\prime \prime}$ & Plantation & 20 \\
\hline 10. & Dharwad KA & $15^{\circ} 27^{\prime} 36.90^{\prime \prime}$ & $75^{\circ} 0^{\prime} 37.02^{\prime \prime}$ & Natural & 10 \\
\hline 11. & Hassan KA & $13^{\circ} 00^{\prime} 29.9^{\prime \prime}$ & $76^{\circ} 06^{\prime} 10.8^{\prime \prime}$ & Plantation & 11 \\
\hline 12. & Chennarayapatna KA & $13^{\circ} 04^{\prime} 35.1^{\prime \prime}$ & $77^{\circ} 20^{\prime} 57.6^{\prime \prime}$ & Natural & 10 \\
\hline 13. & Gottipura KA & $13^{\circ} 23^{\prime} 0.96^{\prime \prime}$ & $76^{\circ} 21^{\prime} 38.4^{\prime \prime}$ & Plantation & 10 \\
\hline 14. & Shimogga KA & $13^{\circ} 55^{\prime} 47.70^{\prime \prime}$ & $75^{\circ} 34^{\prime} 5.16 .0^{\prime \prime}$ & Plantation & 10 \\
\hline
\end{tabular}

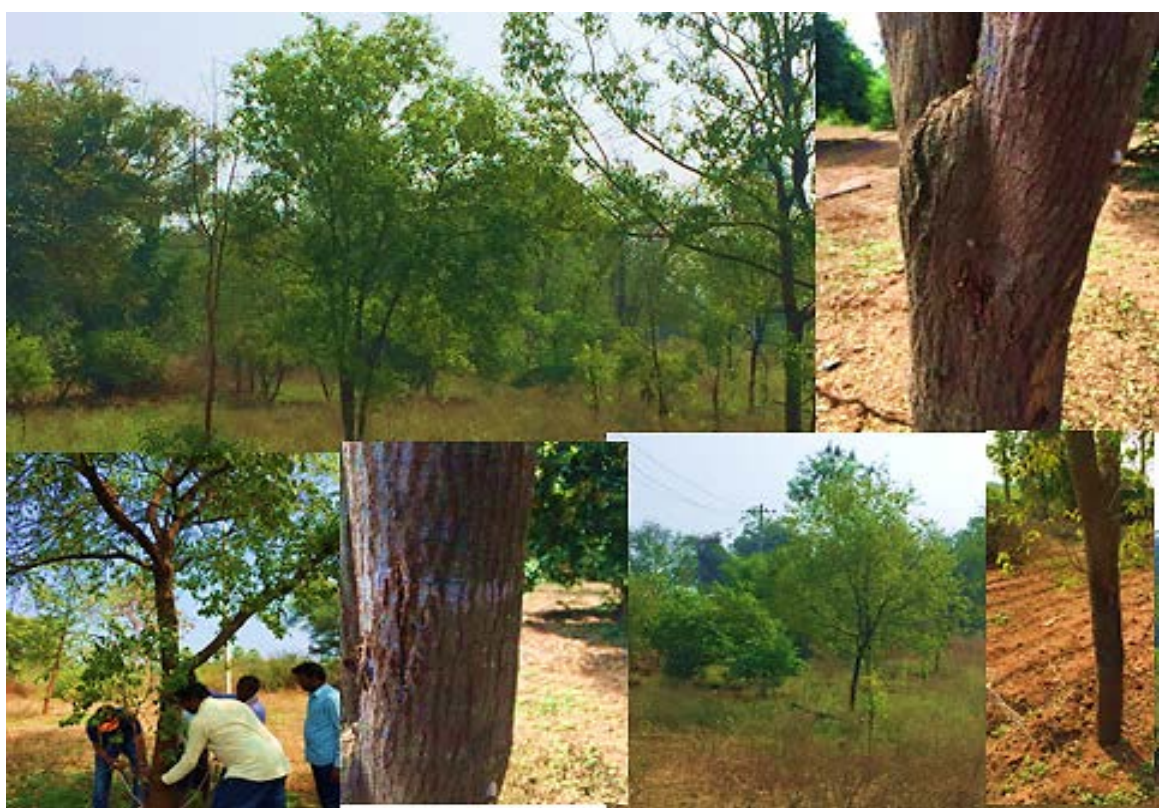

Figure 2. 15 years old plantation of Sandalwood in Suryapet Telangana state showing girth of stem and tree bearing leaves.

populations (natural and plantation) in Southern India including Karnataka, Telangana state and Kerala by using modified CTAB method [6] [7]. The yield of extracted DNA was quantified by Nano drop at 260/280 nm wavelength in basic Eppendorf spectrophotometer. The purity of DNA was checked by running the samples on $0.8 \%$ agarose gel. 
d) Screening and selection of microsatellite markers: Total 44 developed primers for other sandalwood species (O. lanceolata, [8], S. austrocaledonicum [9] S. insulare [10] and S. spicatum [11] were screened for cross amplification of extracted DNA of $S$. album. 25 primers (Table 2) were amplified and generated polymorphism with the selected genotypes for the genetic diversity study.

e) PCR Standardization of PCR (Polymerase Chain Reaction): Polymerase chain reaction (PCR) was performed according to the protocol developed by [12]. The PCR amplifications were carried out in $0.2 \mathrm{~mL}$ tube in Mastercycler gradient (Thermo scientific, Germany) in $13 \mu \mathrm{L}$ reaction volume. The reaction mixture containing $2 \mu \mathrm{L}(30 \mathrm{ng} / \mu \mathrm{L})$ of genomic DNA as template DNA, $1.5 \mu \mathrm{L}$ of 10× PCR buffer, $1.5 \mu \mathrm{L} 15 \mathrm{mM} \mathrm{MgCl}, 2 \mu \mathrm{L} 10 \mathrm{mM}$ SSR primers (Eurofins Pvt. Ltd.), $10 \mathrm{mM}$ dNTPs and $0.2 \mu \mathrm{L}(3 \mathrm{U} / \mu \mathrm{L}$ ) Taq polymerase (Genie, Bangalore Pvt. Ltd.) and $4.4 \mu \mathrm{L}$ double distilled water to maintain the volume. Amplification reactions were carried out with cycle profiles viz; initial denaturation at $94^{\circ} \mathrm{C}$ for 3 minutes, followed by 30 cycles of denaturation at $94^{\circ} \mathrm{C}$ for $30 \mathrm{sec}$, primer annealing at $50^{\circ} \mathrm{C}-65^{\circ} \mathrm{C}$ (depends on the primer melting temperature) for $1 \mathrm{~min}$, extension at $72^{\circ} \mathrm{C}$ for $2 \mathrm{~min}$ and a final extension of $10 \mathrm{~min}$ at $72^{\circ} \mathrm{C}$ temperature.

f) Separation and detection of amplified PCR products: The amplification products were size separated by gel electrophoresis in $4 \%$ agarose [13] gel in $1 \times$ TAE buffer at a constant $80 \mathrm{~V}$ current for $4 \mathrm{~h}$ and stained in ethidium bromide solution and gel mixture was observed in UV light provided by a trans-illuminator in (Syngene G: Box) gel documentation system to visualize the bands. The size of the amplification products generated was estimated by using a standard molecular weight ladder depends upon the product size (50 bp and 100 bp Fermentas Thermofisher pvt. Ltd.).

g) Microsatellite marker Statistical data analysis: Due to bi-allelic nature of S. album the allele information for 25 loci from selected individuals was assembled as a co-dominant data. The samples were categorized according to sample wise of all populations, and region wise. GenAlex v 6.5 [14] [15] was used to estimates the following genetic diversity parameters at individual level and population level; Number of alleles (Na), Effective number of alleles (Ne), Observed heterozygosity (Ho), Expected heterozygosity (He), Shannon information index (I), F statistics $\left(\mathrm{F}_{\mathrm{IS}} \mathrm{F}_{\mathrm{IT}} \& \mathrm{~F}_{\mathrm{ST}}\right.$ ), Polymorphic information content (PIC) (Cervus 3.0.3) and Nie's genetic distance (1978) were estimated at the population level. Gene flow was calculated by using the formula $\mathrm{Nm}=0.25\left(1-\mathrm{F}_{\mathrm{ST}}\right) / \mathrm{F}_{\mathrm{ST}}$. Analysis of molecular variance (AMOVA) used to determine the genetic variations in between the populations and among the populations. A phylogenetic tree distance-based cluster analysis was performed and dendrogram based on the unweighted pair group method of arithmetic mean (UPGMA) was constructed using Jaccard's similarity coefficient was based on neighbour joining method constructed in popgen version 3.2 [16] at 0.05 significance level.

h) STRUCTURE and PCA (Principle Component Analysis): An unbiased Bayesian approach using Markov chain Monte carlo (MCMC) clustering of 
Table 2. List of selected SSR primers for Santalum album. F: Forward; R: Reverse primers.

\begin{tabular}{|c|c|c|c|c|c|c|c|c|}
\hline SI. No. & Locus & $\begin{array}{l}\text { Accession } \\
\text { No. }\end{array}$ & Primer sequences $\left(5^{\prime}-3^{\prime}\right)$ & $\begin{array}{l}\text { No. } \\
\text { of bp. }\end{array}$ & $\begin{array}{c}\text { Repeat } \\
\text { motif }\end{array}$ & $\begin{array}{l}\mathrm{Tm} \\
\left({ }^{\circ} \mathrm{C}\right)\end{array}$ & $\begin{array}{l}\text { Allele range size } \\
\text { in species (bp) }\end{array}$ & $\begin{array}{l}\text { Allele size range } \\
\text { in } S \text {. album (bp) }\end{array}$ \\
\hline \multicolumn{9}{|c|}{ Osyris lanceolata } \\
\hline 1. & KFOL2 & LC126834 & $\begin{array}{l}\text { F: AGAATGTCATTTGAAGGCTCGA } \\
\text { R: CCTTTCCTCCGTTCTCCTCG }\end{array}$ & $22 / 20$ & CGTC & 57 & $178-194$ & $170-190$ \\
\hline 2. & KFOL8 & LC154966 & $\begin{array}{l}\text { F: GCTGCTTCTACGGTCACTGT } \\
\text { R: GTGGTGGATATGGAGGTGGC }\end{array}$ & $20 / 20$ & CCG & 58 & $120-130$ & $150-170$ \\
\hline 3. & KFOL28 & LC126839 & $\begin{array}{l}\text { F: ATAAAGGCCCACGAGCTCAG } \\
\text { R: AACATCGCCATGCAGAACAG }\end{array}$ & $20 / 20$ & $\mathrm{CT}$ & 60 & $320-350$ & $330-350$ \\
\hline 4. & KFOL42 & LC126843 & $\begin{array}{l}\text { F: AGGTCCTCCTGCCTGAGAAT } \\
\text { R: CATAGGGCTGTGATGCCTCA }\end{array}$ & $20 / 20$ & TG & 61 & $270-300$ & $300-315$ \\
\hline 5. & KFOL16 & LC154968 & $\begin{array}{l}\text { F: TGGAGCCCATTCTCTTTCCTT } \\
\text { R: TGCACGTATTCCACATTTCCA }\end{array}$ & $21 / 21$ & GT & 59 & $130-160$ & $140-165$ \\
\hline 6. & KFOL19 & LC154969 & $\begin{array}{l}\text { F: GGTAGCGAGCGGTGATATGT } \\
\text { R: ACCTAACAACTTGAAGCTCTCCC }\end{array}$ & $20 / 23$ & $\mathrm{TC}$ & 57 & $200-230$ & $275-292$ \\
\hline 7. & KFOL29 & LC154961 & $\begin{array}{l}\text { F: GCTGAATCAGGGACAGGCAT } \\
\text { R: GGCCTCGAACAAAGTGCATG }\end{array}$ & $20 / 20$ & GA & 56 & $230-250$ & $159-170$ \\
\hline 8. & KFOL30 & LC126840 & $\begin{array}{l}\text { F: CTAAACTGTCAGGGCTTGCT } \\
\text { R: ATACCTTAGCTCCCGTTGCG }\end{array}$ & $20 / 20$ & TC & 55 & $270-250$ & $195-208$ \\
\hline 9. & KFOL37 & LC126841 & $\begin{array}{l}\text { F: TTTCTAGAGCTAACATACCTCTGAA } \\
\text { R: ATGACCTGGGTGCTTTGCTG }\end{array}$ & $25 / 20$ & TG & 59 & $270-306$ & $265-310$ \\
\hline 10. & KFOL17 & LC12836 & $\begin{array}{l}\text { F: CATTGACGAATTGCATCCCGT } \\
\text { R: CGTGAAGTTCAGTGCAAACC }\end{array}$ & $21 / 20$ & AG & 60 & $160-175$ & $165-178$ \\
\hline 11. & KFOL24 & LC126838 & $\begin{array}{l}\text { F: CAACTCGATCGTGCATTGGC } \\
\text { R: TCCGCATATCCATTTGGCCG }\end{array}$ & $20 / 20$ & $\mathrm{CT}$ & 61 & $200-220$ & $205-218$ \\
\hline 12. & KFOL13 & LC126835 & $\begin{array}{l}\text { F: TCCGAGGAACAGGGACTCTT } \\
\text { R: AGCGAAGAACTCATGAGCGAA }\end{array}$ & $20 / 21$ & $\mathrm{AC}$ & 60 & $140-155$ & $100-115$ \\
\hline 13. & KFOL27 & LC154970 & $\begin{array}{l}\text { F: CTAAACTGTCAGGGCTTGCT } \\
\text { R:ATACCTTAGCTCCCGTTGCG }\end{array}$ & $20 / 20$ & ATG & 61 & $135-150$ & $200-211$ \\
\hline 14. & KFOL15 & LC154967 & $\begin{array}{l}\text { F: CATTGACGAATTGCATCCCGT } \\
\text { R: CGTGAAGTTCAGTGCAAACC }\end{array}$ & $21 / 20$ & CGC & 60 & $170-185$ & $180-200$ \\
\hline 15. & KFOL7 & LC154965 & $\begin{array}{l}\text { F: CTGTGCAATGGAGAAGGCCA } \\
\text { R: CGCGGGATTGGGATGTCATA }\end{array}$ & $20 / 20$ & ATT & 61 & $250-350$ & $260-320$ \\
\hline \multicolumn{9}{|c|}{ Santalum austrocaledonicum } \\
\hline 16. & mSaCIRE09 & AJ831397 & $\begin{array}{l}\text { F: GGAAAGGGTTGACAGGAAAGAAAA } \\
\text { R: TGCCAGTGAGTGGGAAAGTAGA }\end{array}$ & $24 / 22$ & $(\mathrm{CT})_{16}$ & 59 & $179-190$ & $174-187$ \\
\hline 17. & mSiCIR153 & AM113984 & $\begin{array}{l}\text { F: ATGCTTTTGTGGTGATTC } \\
\text { R:GCTTGGAGGTATCTTGTTGG }\end{array}$ & $18 / 20$ & $(\mathrm{CA})_{2} \mathrm{GA}$ & 58 & $210-220$ & $180-215$ \\
\hline 18. & $\mathrm{mSaCIRH} 10$ & AJ831403 & $\begin{array}{l}\text { F: AAGCCCGATAACGAGAAAAGAAA } \\
\text { R: ATGAATAGGGATGGCGAGAGGAT }\end{array}$ & $23 / 23$ & $(\mathrm{GA})_{27}$ & 59 & $117-130$ & $118-132$ \\
\hline 19. & mSaCIRH09 & AJ831402 & $\begin{array}{l}\text { F: GCCTCTGCTTCCTCCCATTGTAG } \\
\text { R: AACTCCATTTGTGATTCCTCCCA }\end{array}$ & $23 / 23$ & $(\mathrm{GA})_{20}$ & 59 & $150-170$ & $200-212$ \\
\hline 20. & mSaCIRG10 & AJ831401 & $\begin{array}{l}\text { F: GTGCTACCTGCTACCCTTTTT } \\
\text { R: CCAATAACGGCTTCAACTTCA }\end{array}$ & $21 / 21$ & $(\mathrm{CA})_{7}$ & 50 & $160-170$ & $159-168$ \\
\hline \multicolumn{9}{|c|}{ Santalum insulare } \\
\hline 21. & $\mathrm{mSiCIR33}$ & AM113978 & $\begin{array}{l}\text { F: GAAGTTGAAGTTGTTGATGC } \\
\text { R: AAATGAGAGACCTGAGTGAAG }\end{array}$ & $20 / 21$ & $(\mathrm{TC})_{19}$ & 58 & $176-199$ & $169-198$ \\
\hline 22. & $\mathrm{mSiCIR} 42$ & AM113980 & $\begin{array}{l}\text { F: CGCACAAACTAAAAACCCT } \\
\text { R: TCGTAATGGATGGCTTCTTCTA }\end{array}$ & $19 / 22$ & $(\mathrm{GA})_{11}$ & 58 & $122-135$ & $230-250$ \\
\hline 23. & mSiCIRF10 & AJ831398 & $\begin{array}{l}\text { F: TTAGGAAACATAGCACACT } \\
\text { R: GAGCACTTCACCACCATTAC }\end{array}$ & $19 / 20$ & $(\mathrm{GA})_{17}$ & 59 & $200-220$ & $149-162$ \\
\hline
\end{tabular}




\section{Continued}

\begin{tabular}{rrrllllll}
\hline \multicolumn{7}{c}{ Santalum. Spicatum } \\
\hline 24. & SsB112 & EU287768 & $\begin{array}{l}\text { F: GGAGCAAGCTAAGCACAC } \\
\text { R: GCAGCCAAGAAAAATTACTAC }\end{array}$ & $18 / 21$ & $\left.(\mathrm{TC})_{16} \mathrm{AC}\right)_{11}$ & 60 & $213-238$ & $220-233$ \\
25. & SsB122 & EU287769 & $\begin{array}{l}\text { F: AGGTGCGTCTCTTTCATACTA } \\
\text { R: CAGTCGTTTCGGTCACA }\end{array}$ & $21 / 17$ & $(\mathrm{CT})_{19}$ & 60 & $234-273$ & $240-252$ \\
\hline
\end{tabular}

samples was conducted via the STRUCTURE v2.2.3 software

(http://www.stats.ox.ac.uk/) [17]. Parameters were set as diploid data for each individual and assessed for values of $\mathrm{K}$ ranging from 1 to 11 Burn in MCMC iteration setting were 50000 and 100000 respectively. Allele frequencies were correlated for each value of $\mathrm{K}, 10$ replicate simulations using a model allowing for admixture used correlated allele frequencies. Data from each sample analysis were combined and $\Delta \mathrm{K}$ statistics calculated using Structure harvester [18] as for the microsatellite marker analysis. The appropriate value for $\Delta \mathrm{K}$ was estimated from $\operatorname{LnP}(\mathrm{K})$ value described by $\Delta \mathrm{K}=\mathrm{m}(|\mathrm{L} " \mathrm{~K}|) / \mathrm{s}[\mathrm{L}(\mathrm{K})][19]$ and an adhoc method based on the second rate order rate of change of the likelihood $(\Delta \mathrm{K})$ described by [20]. Principal component analysis was performed to show the differentiation of the $S$. album accessions in two-dimensional array of eigen vector using the variance and eigen module [21]. PCA is a prominent development in genotypes collections from different geographical locations that allows a better understanding of the entirely different populations. PCA was executed for all the accessions by using Minitab v.18. by using the selected microsatellite markers. PCA used to represent genetic relations among the accessions from different geographical locations.

\section{Results}

i) DNA quantification: The quality of extracted DNA was quantified by running the $3 \mu \mathrm{L}$ DNA on $0.8 \%$ agarose gel in $1 \mathrm{X}$ TAE buffer stain containing $4 \mu \mathrm{L}$ of $0.3 \%$ ethidium bromide solution checked the purity of DNA Figure 3 .

ii) SSR marker amplification and polymorphism: All markers produced polymorphic amplification bands in selected genotypes Figure 4, which ranged from 120 - 350 bp. 15 to 6 number of alleles was generated at each locus with total 172 alleles. High polymorphism was found in LC154966, LC126838, LC126839, LC154969 and LC154965 which were specifically belongs to O. lanceolata and AJ831401, AJ831403, EU287768 was showing low polymorphism. AJ831397 AJ831398 primers were gradient polymorphic and AM113980, LC154967, LC154970, LC126840 and LC126843 was non-repeatable stable monomorphic in each population.

iii) Genetic diversity: In this study highest number of alleles (Na) (10.05) with the average of 8.98 was found in Karnataka state followed by Kerala and Telangana 8.838 .03 respectively. In Kerala state the observed and expected heterozygosity was 0.168 and 0.847 , which revealed the very low genetic diversity in Kerala populations (Table 3). Total numbers of alleles were ranged from (16.5 - 6.7) LC154969 in LC154961 followed by Kodada Telangana state and Marayur 


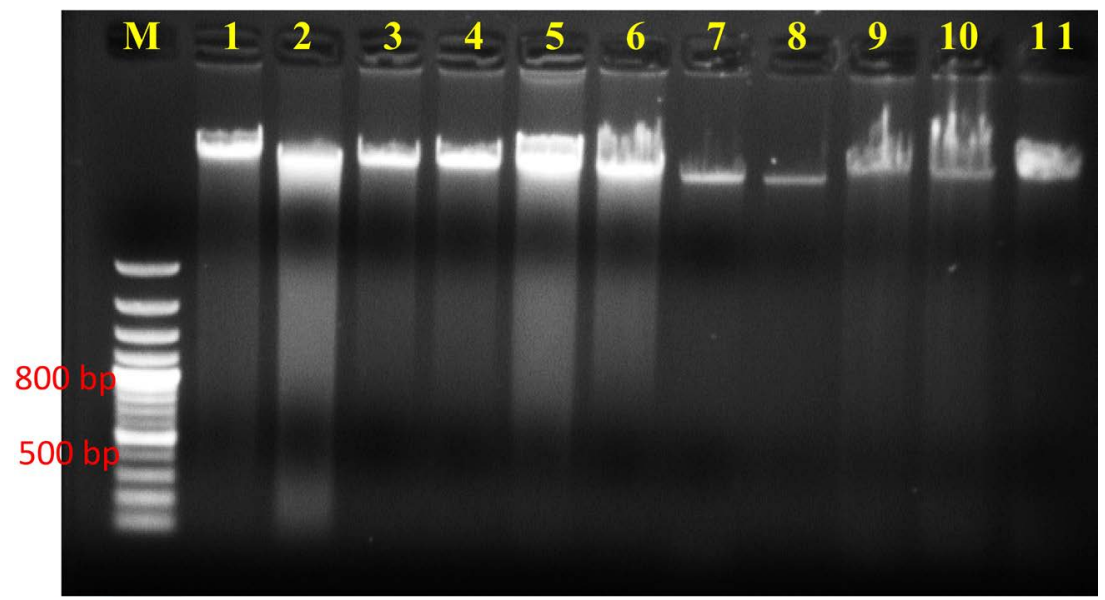

Figure 3. Sandalwood genomic DNA extracted by modified CTAB protocol.
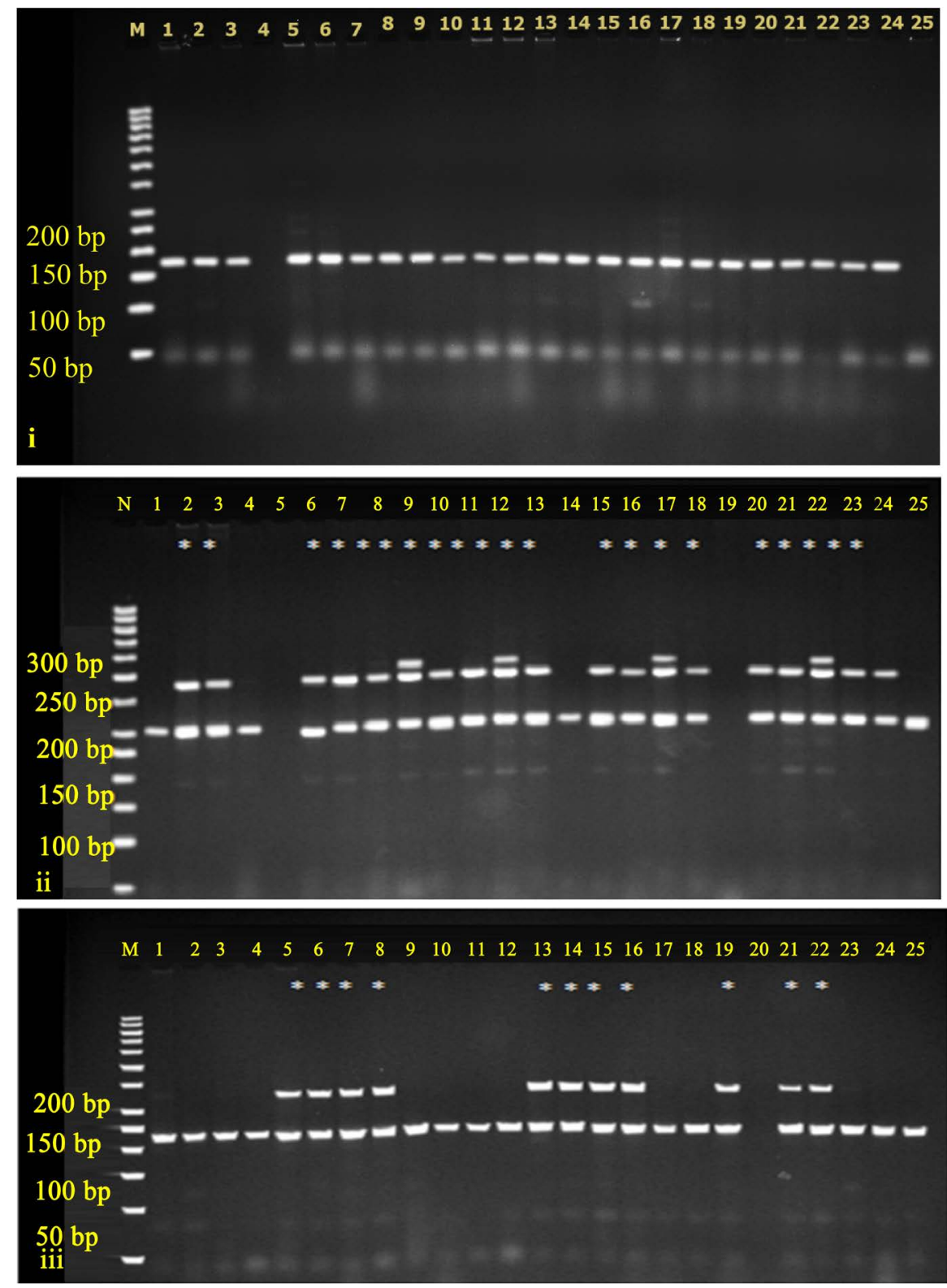


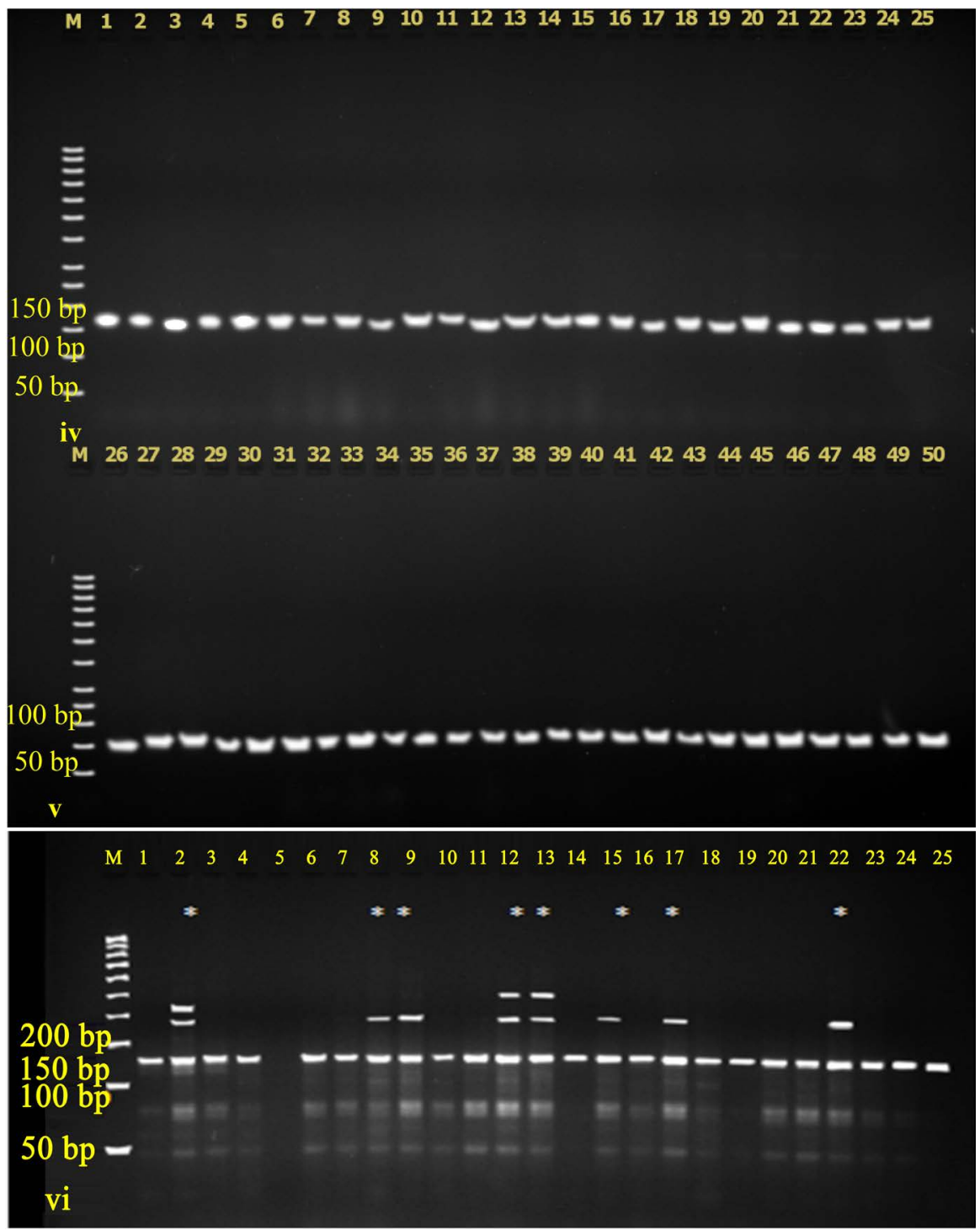

Figure 4. Amplification and polymorphism profile of $S$. album L. accessions using SSR markers. M: Ladder (50 bp. Fermentas Thermofisher pvt. ltd.) i. LC154967 (O. lanceolata) ii. AM113984 (S. austrocaledonicum) iii. AJ831401 (S. austrocaledonicum) iv. AJ831397 (S. austrocaledonicum) v. AJ831398 (S. insulare) vi. AJ831403 (S. austrocaledonicum).

Table 3. Mean and standard error of $\mathrm{Na}, \mathrm{Ne}, \mathrm{Ho}, \mathrm{He}, \mathrm{F}$ and I for over all three states using microsatellite markers.

\begin{tabular}{ccccccc}
\hline State & $\mathrm{Na}$ & $\mathrm{Ne}$ & $\mathrm{Ho}$ & $\mathrm{He}$ & $\mathrm{I}$ & $\mathrm{F}$ \\
\hline Karnataka & 10.05 & 8.09 & 0.187 & 0.861 & 2.03 & 0.89 \\
Kerala & 8.83 & 7.17 & 0.168 & 0.847 & 2.005 & 0.81 \\
Telangana & 8.03 & 7.43 & 0.186 & 0.85 & 2.12 & 0.78 \\
Average & 8.98 & 7.56 & 0.180 & 0.85 & 2.052 & 0.81 \\
\hline
\end{tabular}

location 2. Effective number of alleles was ranged from (0.50 - 0.294) LC154969 and AJ831401 followed by Kodada Telangana followed by Hassan Karnataka. In O. lanceolata, 17 microsatellite markers were developed in which 12 were poly- 
morphic and 5 (LC154965, LC154966, LC154967, LC154970 and LC154961) were monomorphic. In this study out of 15 primers, five were polymorphic (LC154966, LC126834, LC126835, LC126838, LC126839, LC126841, LC154961, LC154968, LC154969 and LC154965) and monomorphic (LC126843, LC12836, LC126840, LC154967 and LC154970). O. lanceolata the no. of alleles per locus was ranged from $(2-17)$ with the average 8.05 where as in this study total no. of alleles per locus in $S$. album was observed by these markers were ranged from (6 - 16.55) with the average of 9.33. The no. of alleles across the total 14 populations ranged from Marayur location 2 Kerala 7.90 to 11.65 Kodada Telangana. In $O$. lenaceolata the expected heterozygosity was ranged from $0.00-0.77$ while in S. album it was found 0.54 (Marayur Kerala, Chennarayapatna and Shimogga Karnataka) to 0.927 Kodada, Suryapet Telangana and IWST Bangalore Karnataka [8]. Highest observed heterozygosity (Ho) was found in AM113984 and lowest was found in LC154967 surveyed by Chennarayapatna Karnataka and Marayur location 2 Kerala. Highest expected heterozygosity was found in LC154969 and lowest was obtained in LC126834 and in population it was Suryapet Telangana and lower was in Marayur location 1 Kerala. Shannon information index was ranged from (2.435 - 1.69) followed by Marayur location 3 and in lowest in IWST Karnataka (1.93 - 2.2). Fixation index was highest in 968 and lowest in - 0.082 followed by Dharwad and Hassan Karnataka $(0.77$ - 0.83) Table 4 and Table 5.

Table 4. Mean and Standard error (SE) for each Locus, Sample Size (N), no. of alleles (Na), effective no. of alleles (Ne), Shannon Information Index (I), Observed heterozygosity (Ho), Expected heterozygosity (He) and Fixation Index (F) over all populations using microsatellite markers.

\begin{tabular}{|c|c|c|c|c|c|c|c|c|c|c|c|c|c|}
\hline \multirow{2}{*}{ Population } & \multirow{2}{*}{$\mathbf{N}$} & \multicolumn{2}{|c|}{$\mathrm{Na}$} & \multicolumn{2}{|c|}{$\mathrm{Ne}$} & \multicolumn{2}{|c|}{ Ho } & \multicolumn{2}{|c|}{$\mathrm{He}$} & \multicolumn{2}{|c|}{$\mathbf{F}$} & \multicolumn{2}{|c|}{ I } \\
\hline & & Mean & SE & Mean & SE & Mean & SE & Mean & SE & Mean & SE & Mean & SE \\
\hline Kodada TS & 22 & 11.650 & 1.139 & 8.778 & 0.754 & 0.191 & 0.088 & 0.869 & 0.012 & 0.795 & 0.095 & 2.224 & 0.091 \\
\hline Suryapet TS & 22 & 11.200 & 0.99 & 8.59 & 0.70 & 0.173 & 0.083 & 0.87 & 0.008 & 0.81 & 0.094 & 2.21 & 0.07 \\
\hline Khammam TS & 10 & 8.500 & 0.74 & 7.37 & 0.65 & 0.180 & 0.084 & 0.84 & 0.011 & 0.80 & 0.89 & 2.00 & 0.65 \\
\hline Hyderabad TS & 10 & 8.750 & 0.63 & 7.61 & 0.56 & 0.200 & 0.092 & 0.85 & 0.009 & 0.78 & 0.092 & 2.056 & 0.56 \\
\hline Marayur $1 \mathrm{KL}$ & 12 & 9.50 & 0.74 & 7.86 & 0.64 & 0.183 & 0.084 & 0.85 & 0.010 & 0.79 & 0.100 & 2.104 & 0.64 \\
\hline Marayur $2 \mathrm{KL}$ & 10 & 7.90 & 0.59 & 6.60 & 0.49 & 0.150 & 0.082 & 0.83 & 0.009 & 0.83 & 0.092 & 1.93 & 0.49 \\
\hline Marayur L3 KL & 10 & 8.15 & 0.60 & 7.07 & 0.54 & 0.170 & 0.082 & 0.84 & 0.010 & 0.81 & 0.091 & 1.97 & 0.54 \\
\hline IWST Bangalore KA & 20 & 11.500 & 0.94 & 9.05 & 0.80 & 0.200 & 0.092 & 0.87 & 0.008 & 0.78 & 0.090 & 2.2 & 0.80 \\
\hline Nelamangala KA & 10 & 8.75 & 0.699 & 7.52 & 0.58 & 0.150 & 0.092 & 0.85 & 0.009 & 0.78 & 0.098 & 2.04 & 0.58 \\
\hline Hassan KA & 11 & 8.05 & 0.651 & 6.94 & 0.60 & 0.160 & 0.082 & 0.84 & 0.010 & 0.83 & 0.100 & 1.95 & 0.60 \\
\hline Chennarayapatna KA & 10 & 8.10 & 0.59 & 6.913 & 0.521 & 0.200 & 0.082 & 0.85 & 0.012 & 0.82 & 0.090 & 1.96 & 0.52 \\
\hline Dharwad KA & 10 & 8.30 & 0.73 & 7.264 & 0.644 & 0.200 & 0.092 & 0.84 & 0.011 & 0.78 & 0.089 & 1.98 & 0.64 \\
\hline Gottipura KA & 10 & 8.45 & 0.65 & 7.16 & 0.534 & 0.200 & 0.092 & 0.84 & 0.08 & 0.77 & 0.101 & 2.00 & 0.53 \\
\hline Shimogga KA & 10 & 8.65 & 0.72 & 7.16 & 0.621 & 0.184 & 0.083 & 0.84 & 0.011 & 0.78 & 0.101 & 2.00 & 0.62 \\
\hline Overall pop & 177 & 9.10 & 0.743 & 7.56 & 0.616 & 0.181 & 0.0864 & 0.84 & 0.015 & 0.796 & 0.151 & 2.044 & 0.523 \\
\hline
\end{tabular}




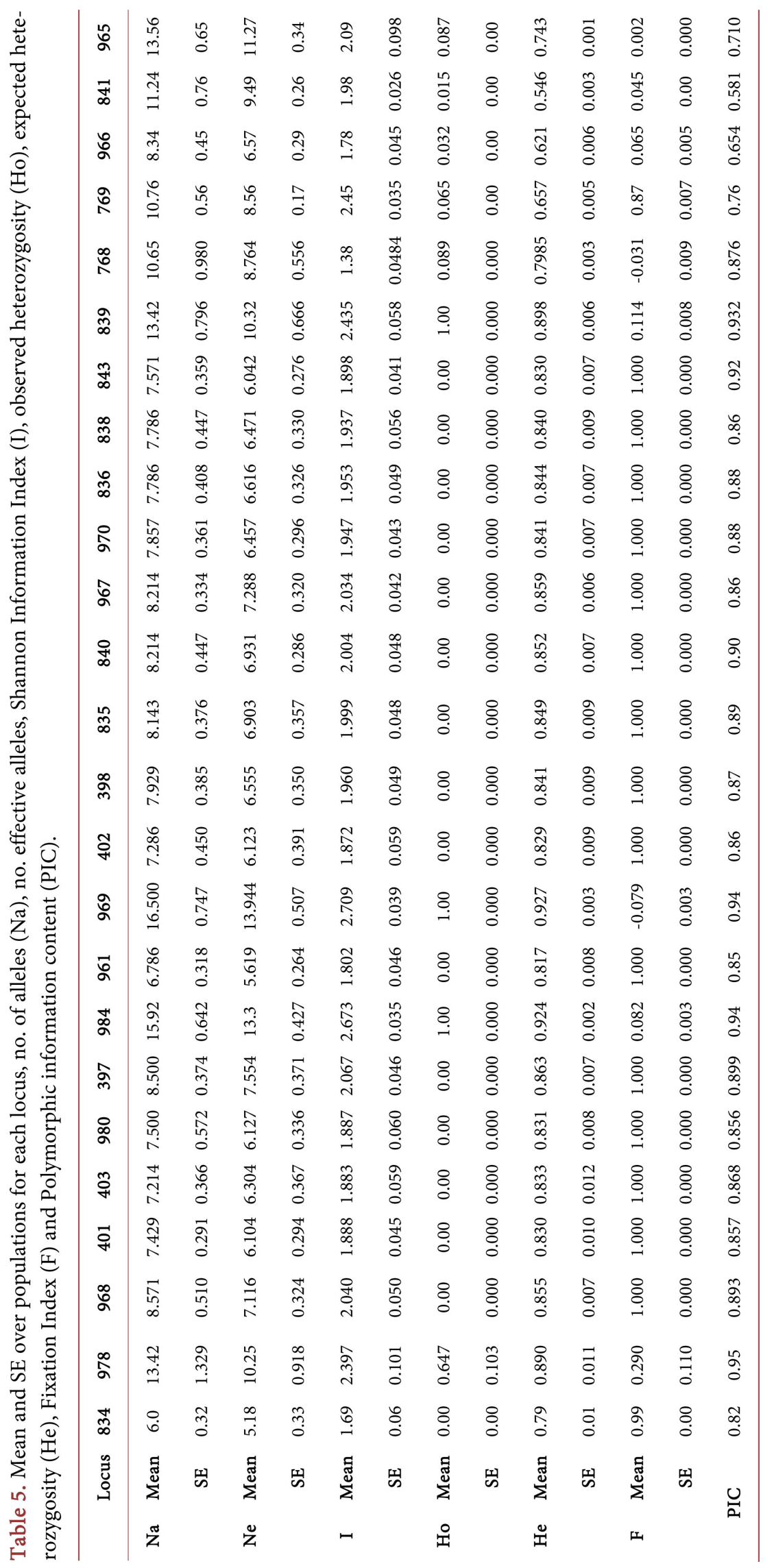


From Figure 5, it was clearly depicted that IWST Bangalore Suryapet, Kodada populations were showing high expected heterozygosity whereas Kerala populations were presenting very low expected heterozygosity which indicated the low genetic diversity and high homozygosity in Kerala populations than Telangana and Karnataka Populations.

AMOVA revealed that $3 \%$ of the total variation was due to differences among populations and $97 \%$ due to differences within the populations in 25 microsatellite markers in selected populations. The genetic differentiation among populations $\left(\mathrm{F}_{\mathrm{ST}}\right) 0.012$ at $\mathrm{p}<0.001$ was significant Table 6 .

Analysis of the dividing of the genetic variability in $S$. album indicated that it mainly occurred due to within populations and among the individuals variation. In population variability was found only $3 \%$ of the total variation in southern India $(F s t=0.027)$. Gene flow is the movement of genes into or out of the populations. This flow may be due to migration of pollens or genetic drift in different populations. The estimates of gene flow among the populations of Kodada Telangana $(\mathrm{Nm}=15.109)$; IWST Karnataka $(\mathrm{Nm}=13.62)$ than across other geographical populations $(\mathrm{Nm}=9.40)$. Additionally, the estimates of gene flow between Telangana and Kerala $(\mathrm{Nm}=10.178)$ was greater than Telangana and

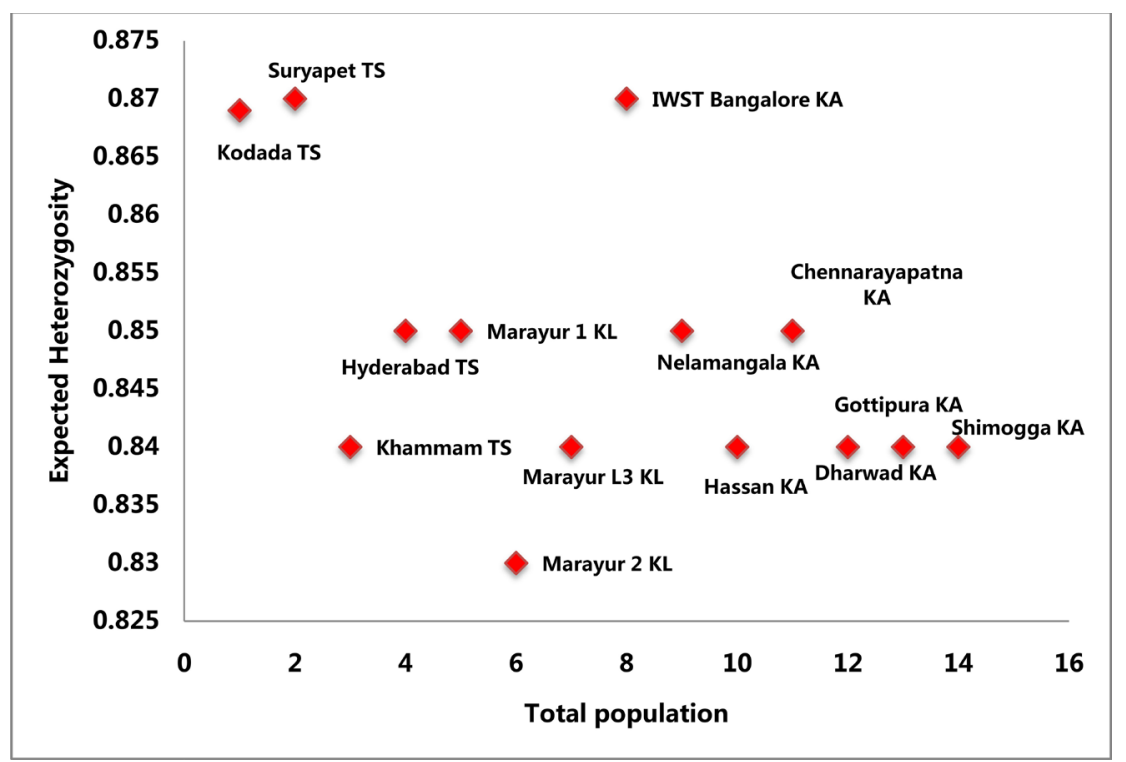

Figure 5. Relationship between Expected heterozygosity and $14 S$. album populations of southern India.

Table 6. Analysis of Molecular Variance (AMOVA) of $S$. album accessions based on genotypes with SSR markers.

\begin{tabular}{cccccc}
\hline Source of Variation & df & SS & $\begin{array}{c}\text { Variance } \\
\text { Component }\end{array}$ & $\begin{array}{c}\text { Estimated } \\
\text { variation }\end{array}$ & \% of variation \\
\hline Among populations & 13 & 152.588 & 11.738 & 0.11 & $3 \%$ \\
Within populations & 340 & 3047.59 & 8.964 & 8.964 & $97 \%$ \\
Total & 353 & 3200.18 & 20.702 & 9.074 & $100 \%$ \\
\hline
\end{tabular}


Karnataka $(\mathrm{Nm}=9.78)$ followed by Kerala and Karnataka $(\mathrm{Nm}=8.49)$. These results suggested that there was a high exchange of genepool between Telangana populations were observed genetically more related to Kerala than Karnataka populations Table 7.

iv) Distribution of Genetic variation: $\mathrm{F}_{\mathrm{IS}}$ and $\mathrm{F}_{\mathrm{IT}}$ reflects the degree of deviation from Hardy Weinberg equilibrium within the populations and among the populations. $\mathrm{F}_{\mathrm{IS}}$ of 14 populations with the selected genotypes of $S$. album ranged from -0.114 of locus LC126839 to 1.00 of several loci (LC126843, LC54968) belongs to O. lanceolata, AJ831397, AJ831398 S. austrocaledonicum and S. insulare with the average 0.80 (Table 8 ) indicated that significant heterozygosity deficiency at LC126839 and AM113984 (O. lanceolata and S. austrocaledonicum). $\mathrm{F}_{\mathrm{ST}}$ as the population differentiation coefficient that measures the degree to genetic differentiation among populations. The lowest $\mathrm{F}_{\mathrm{ST}}$ was obtained in AM113984 and the highest $\mathrm{F}_{\mathrm{ST}}$ was found in $966 . \mathrm{F}_{\mathrm{ST}}$ values of the genetic distance among all the populations were found significant. The evaluations of gene flow into the populations by microsatellite markers was $5.32 S$. album populations. In $S$. austrocaledonicum markers gene flow was observed $(\mathrm{Nm}=6.79)$; in O. lanceolata $(\mathrm{Nm}=5.164) ; S$. insulare $(\mathrm{Nm}=4.492)$ and $S$. spicatum $(\mathrm{Nm}=$ 4.85). This result indicated that the interchange of genetic pools of $S$. album was more related to $S$. austrocaledonicum and $O$. lanceolata.

Nei's genetic distance revealed that the nearest genetic distance was found in between IFB Hyderabad Telangana state and Marayur location 3 populations Table 9. The longest genetic distance was found in between Kodada Telangana

Table 7. F statistics and Nm (Gene flow) of $S$. album populations; $\mathrm{Nm}=[(1 /$ Fst $)-1] / 4$.

\begin{tabular}{|c|c|c|c|}
\hline SI No. & Populations & Fst & $\mathrm{Nm}$ \\
\hline 1. & Kodada TS & 0.016 & 15.109 \\
\hline 2. & Suryapet TS & 0.019 & 12.729 \\
\hline 3. & Khammam TS & 0.023 & 10.686 \\
\hline 4. & Hyderabad TS & 0.027 & 9.081 \\
\hline 5. & Marayur $1 \mathrm{KL}$ & 0.032 & 7.537 \\
\hline 6. & Marayur $2 \mathrm{KL}$ & 0.037 & 6.494 \\
\hline 7. & Marayur L3 KL & 0.025 & 9.610 \\
\hline 8. & IWSKA & 0.032 & 13.624 \\
\hline 9. & Nelamangala KA & 0.018 & 7.565 \\
\hline 10. & Dharwad KA & 0.028 & 8.710 \\
\hline 11. & Hassan KA & 0.032 & 7.469 \\
\hline 12. & Chennarayapatna KA & 0.030 & 8.224 \\
\hline 13. & Gottipura KA & 0.033 & 7.396 \\
\hline 14. & Shimogga KA & 0.026 & 7.428 \\
\hline \multicolumn{2}{|r|}{ Average } & 0.027 & 9.405 \\
\hline
\end{tabular}


Table 8. F statistics and $\mathrm{Nm}$ (Gene flow) of $S$. album microsatellite markers; $\mathrm{Nm}=$ $[(1 /$ Fst $)-1] / 4$.

\begin{tabular}{|c|c|c|c|c|}
\hline Loci & $F_{\mathrm{IS}}$ & $F_{\mathrm{IT}}$ & $F_{\mathrm{ST}}$ & $\mathrm{Nm}$ \\
\hline KFOL2 & 0.99 & 0.99 & 0.06 & 3.38 \\
\hline KFOL8 & 0.87 & 0.76 & 0.076 & 5.61 \\
\hline KFOL28 & -0.11 & -0.08 & 0.029 & 8.31 \\
\hline KFOL42 & 1.00 & 1.00 & 0.096 & 4.48 \\
\hline KFOL16 & 1.00 & 1.00 & 0.050 & 4.79 \\
\hline KFOL19 & -0.07 & -0.05 & 0.021 & 11.85 \\
\hline KFOL29 & 1.00 & 1.00 & 0.057 & 4.16 \\
\hline KFOL30 & 1.00 & 1.00 & 0.055 & 4.25 \\
\hline KFOL37 & 0.85 & 0.43 & 0.065 & 3.46 \\
\hline KFOL17 & 1.00 & 1.00 & 0.058 & 4.03 \\
\hline KFOL24 & 1.00 & 1.00 & 0.06 & 3.70 \\
\hline KFOL13 & 1.00 & 1.00 & 0.062 & 3.77 \\
\hline KFOL27 & 1.00 & 1.00 & 0.040 & 6.05 \\
\hline KFOL15 & 1.00 & 1.00 & 0.059 & 3.97 \\
\hline KFOL7 & 0.35 & 0.26 & 0.064 & 5.65 \\
\hline $\mathrm{mSiCIR} 33$ & 0.27 & 0.32 & 0.064 & 3.62 \\
\hline mSiCIR42 & 1.00 & 1.00 & 0.041 & 5.90 \\
\hline mSiCIR153 & -0.08 & -0.04 & 0.022 & 10.86 \\
\hline mSaCIRE09 & 1.00 & 1.00 & 0.048 & 4.97 \\
\hline mSiCIRF10 & 1.00 & 1.00 & 0.046 & 5.28 \\
\hline mSaCIRH10 & 1.00 & 1.00 & 0.054 & 4.40 \\
\hline mSaCIRH09 & 0.87 & 0.65 & 0.053 & 4.16 \\
\hline $\mathrm{mSaCIRG} 10$ & 1.00 & 1.00 & 0.051 & 3.65 \\
\hline SsB112 & 1.00 & 1.00 & 0.045 & 4.98 \\
\hline SsB122 & 1.00 & 1.00 & 0.053 & 4.72 \\
\hline Average $(=\mathrm{SE})$ & $0.80(0.093)$ & $0.80(0.09)$ & $0.050(0.003)$ & $5.32(0.52)$ \\
\hline
\end{tabular}

state and Dharwad Karnataka populations that indicated that the populations of Telangana state mostly belong to Kerala populations rather than Karnataka populations. These genetic distance results were also justified by the gene flow $(\mathrm{Nm})$ Table 7.

The dendrogram grouped the selected populations into three major clusters. Cluster I involved all Telangana state populations. Cluster II divided into 2 sub-clusters. Sub-cluster I Marayur location 1, IWST KA and Nelamangala KA populations were included and in sub-cluster II included Marayur location 3, Chennarayapatna KA and Gottipura KA. Cluster III divided into 3 sub clusters: sub-cluster I-Shivamogga, sub-cluster II-Marayur location 3 and in sub-cluster III Dharwad, Hassan were included (Figure 6). 
Table 9. Pairwise population matrix of [22] unbiased Nei’s genetic distance.

\begin{tabular}{|c|c|c|c|c|c|c|c|c|c|c|c|c|c|c|}
\hline KOTS & SY TS & Kham TS & Hyd TS & MKE1 & MKE2 & MKE3 & IWKA & NelKA & HasKA & CheKA & DharKA & ShiKA & GoKA & \\
\hline$* * *$ & & & & & & & & & & & & & & KOTS \\
\hline 0.081 & $* * *$ & & & & & & & & & & & & & SY TS \\
\hline 0.095 & 0.012 & $* * *$ & & & & & & & & & & & & Kham TS \\
\hline 0.081 & 0.067 & 0.049 & $* * *$ & & & & & & & & & & & Hyd TS \\
\hline 0.045 & 0.000 & 0.000 & 0.060 & $* * *$ & & & & & & & & & & MKE1 \\
\hline 0.142 & 0.128 & 0.088 & 0.000 & 0.148 & $* * *$ & & & & & & & & & MKE2 \\
\hline 0.198 & 0.099 & 0.111 & 0.057 & 0.095 & 0.193 & $* * *$ & & & & & & & & MKE3 \\
\hline 0.093 & 0.051 & 0.013 & 0.000 & 0.004 & 0.098 & 0.110 & $* * *$ & & & & & & & IWKA \\
\hline 0.182 & 0.106 & 0.053 & 0.005 & 0.118 & 0.078 & 0.092 & 0.007 & $* * *$ & & & & & & NelKA \\
\hline 0.125 & 0.016 & 0.007 & 0.038 & 0.074 & 0.123 & 0.164 & 0.000 & 0.109 & $* * *$ & & & & & HasKA \\
\hline 0.075 & 0.098 & 0.037 & 0.000 & 0.056 & 0.064 & 0.169 & 0.045 & 0.103 & 0.035 & $* * *$ & & & & CheKA \\
\hline 0.222 & 0.184 & 0.074 & 0.120 & 0.178 & 0.286 & 0.179 & 0.101 & 0.117 & 0.045 & 0.114 & $* * *$ & & & DharKA \\
\hline 0.149 & 0.056 & 0.096 & 0.030 & 0.033 & 0.153 & 0.137 & 0.025 & 0.041 & 0.090 & 0.135 & 0.222 & $* * *$ & & ShiKA \\
\hline 0.146 & 0.108 & 0.123 & 0.104 & 0.130 & 0.171 & 0.084 & 0.042 & 0.106 & 0.080 & 0.082 & 0.133 & 0.136 & $* * *$ & GoKA \\
\hline
\end{tabular}

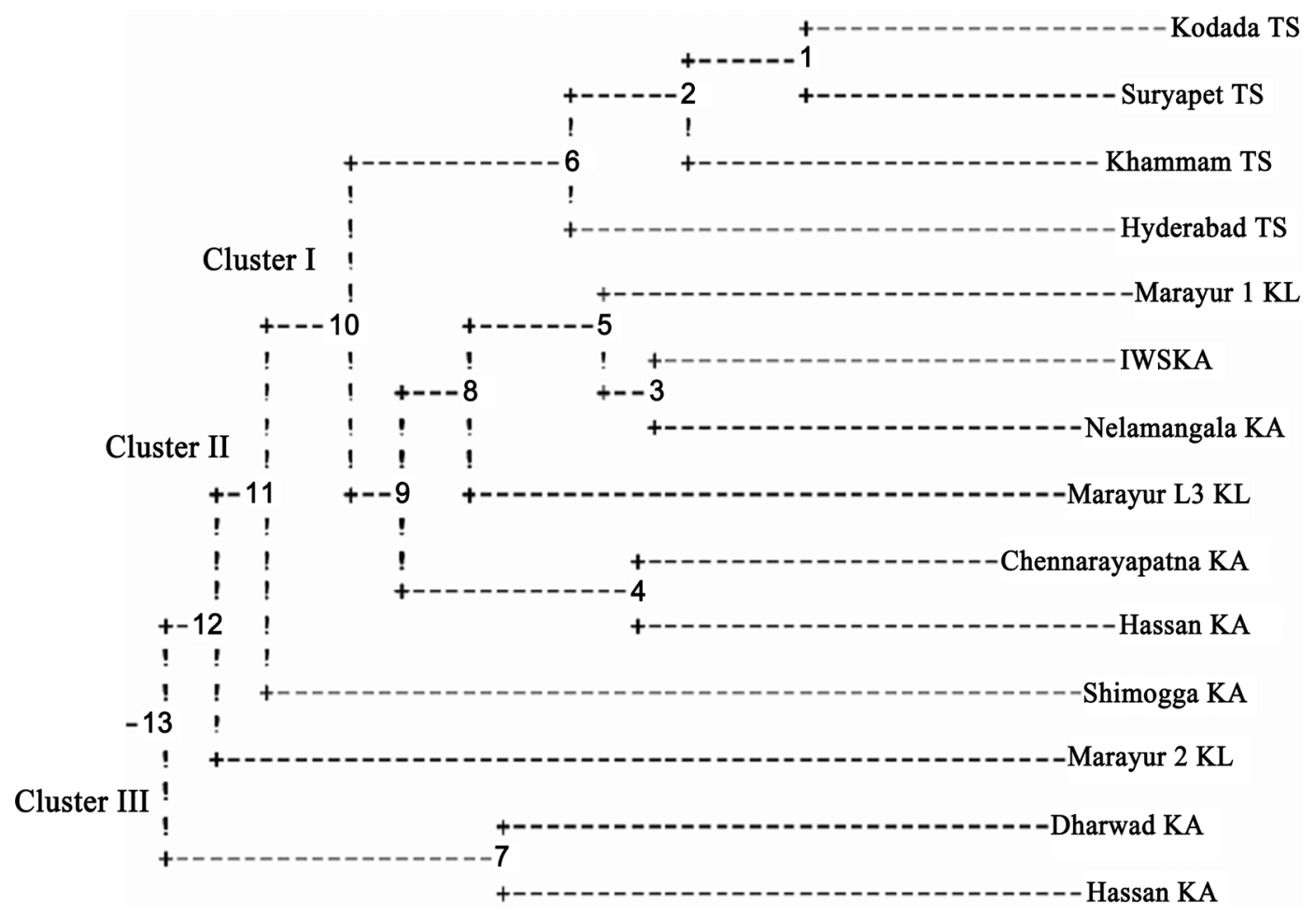

Figure 6. UPGMA Dendrogram for selected populations of $S$. album based on [23] genetic distance method using SSR markers.

Based on UPGMA cluster analysis the 177 accessions were divided into 5 major groups. Group 1 included majority of sandalwood accessions from Karnataka and Telangana state. Within this group 4 sub-groups were observed. Sub group 1 


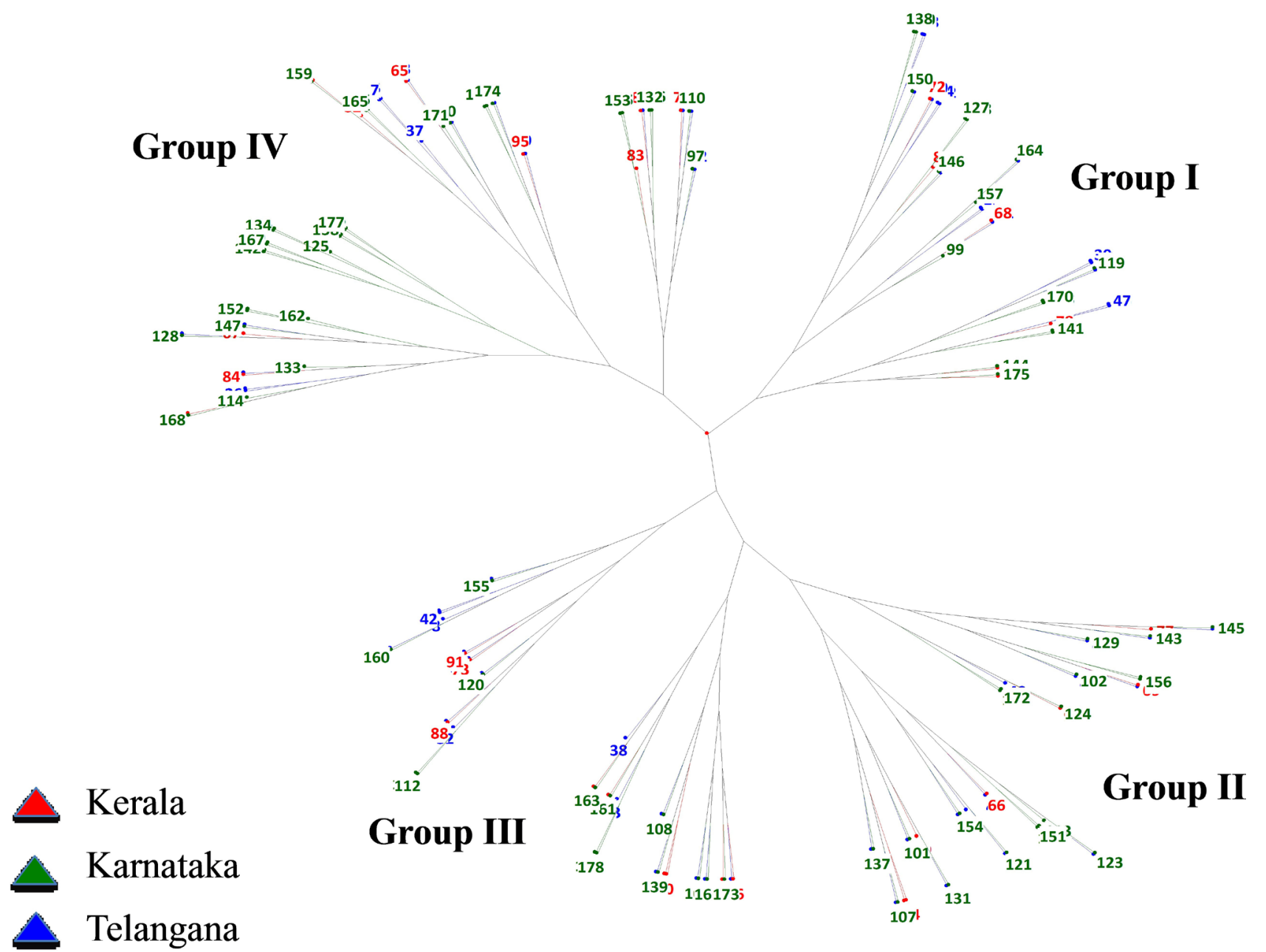

Figure 7. Unweighted pair group methods using arithmetic average algorithm dendrogram (Darwin v. 6.0.17) based on 25 microsatellite (SSR) markers for 177 S. album genotypes.

included Chennarayapatna, Dharwad, Shimogga Karnataka and Kodada Telangana state. In subgroup 2 Chennarayapatna, Nelamangala, IWST Bangalore and Kerala location 1 accessions were grouped. Subgroup 3 included accessions of Nelamangala, Dharwad, Chennarayapatna and few accessions from Kerala and Telangana state. In subgroup 4 included accessions belongs to Nelamangala and Gottipura Hoskote Karnataka. Group 2 included Hassan, Nelamangala, Chennarayapatna, Gottipura, Dharwad and few accessions from Kerala. Group 3 contained within all the accessions from Karnataka state except one genotype from Marayur location 3. Group 4 divided into 3 sub-group in which group 1 included IWST Bangalore, Nelamangala and Gottipura were grouped together and in subgroup 2 included Telangana state $S$. album accession. Mixed accessions of Kerala and Telangana were observed in subgroup 3. Group 5 included Shimogga and Dharwad Karnataka accessions mixed with Telangana and Kerala (Figure 7). Several subgroups were observed in S. album accessions indicated the genetic variability within and among the accessions in each population. 


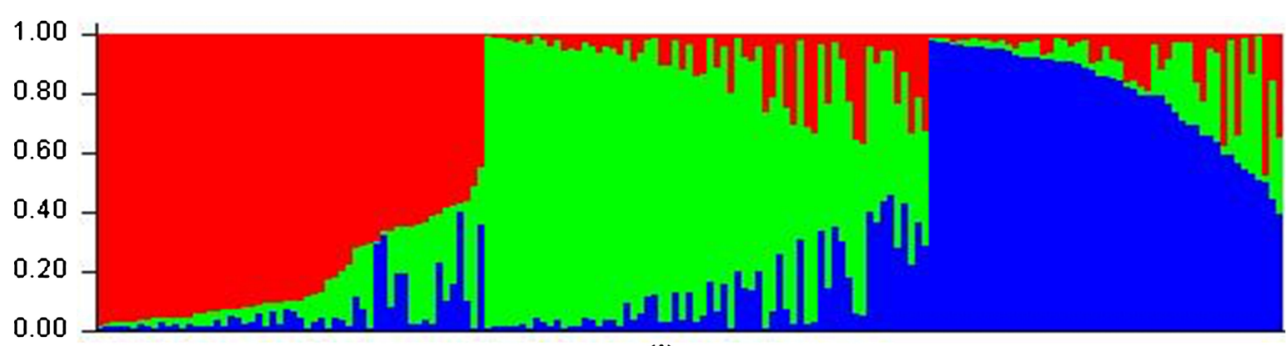

(i)

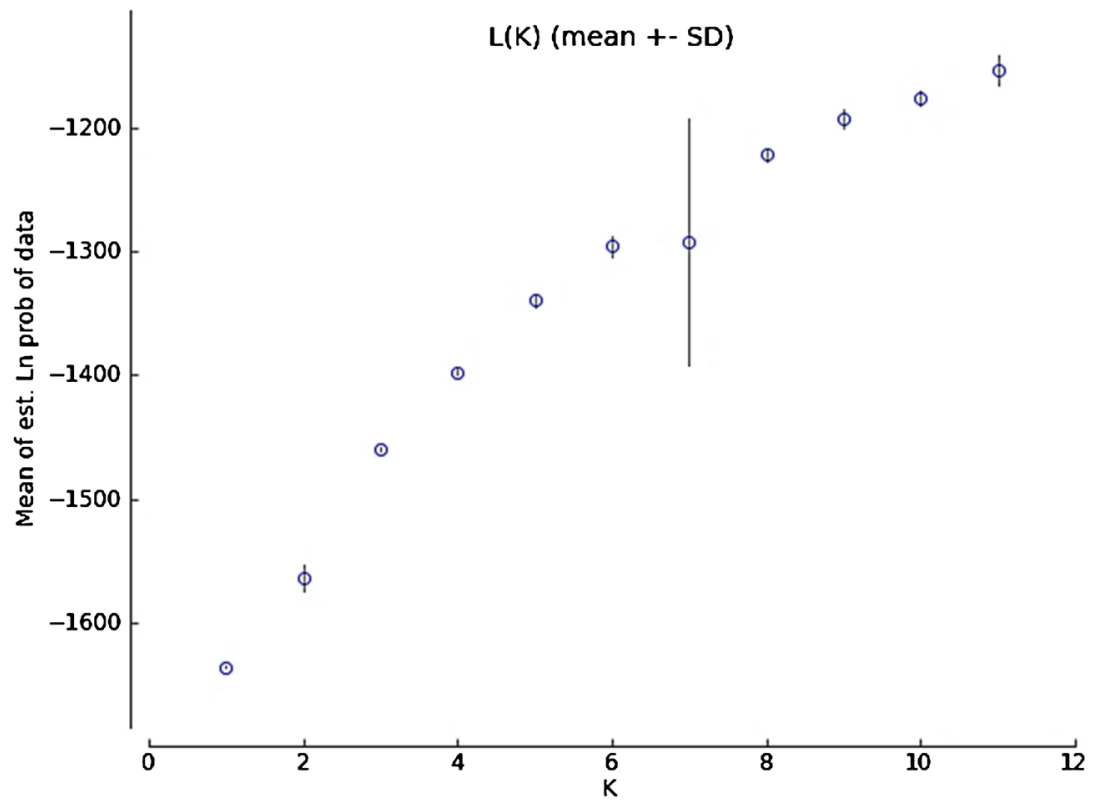

(ii)

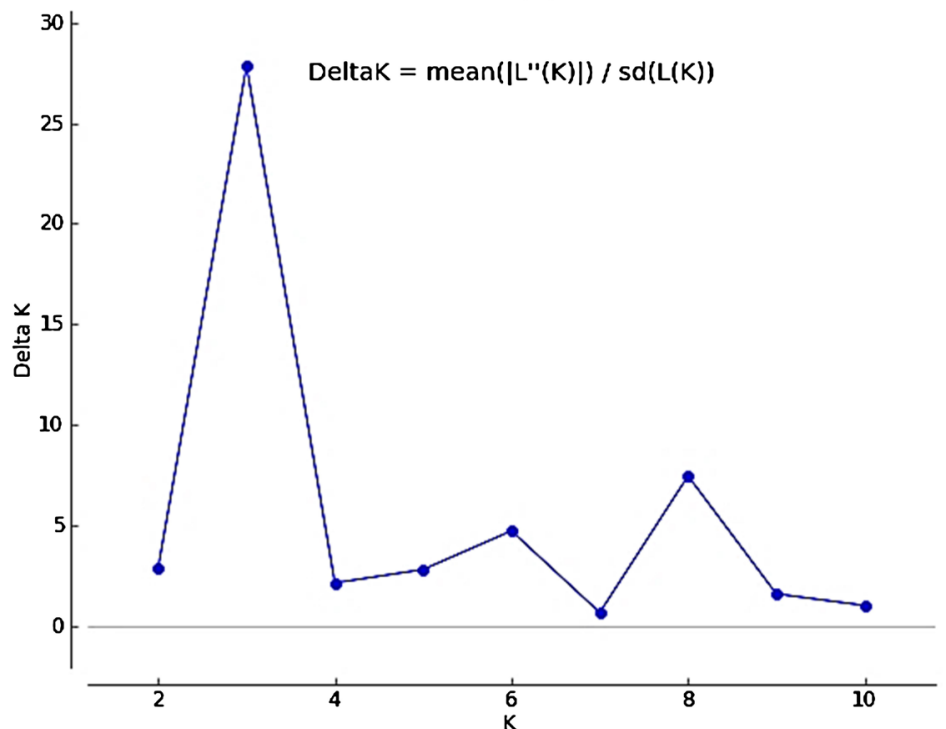

(iii)

Figure 8. Genetic structure plot of 14 S. album populations based on the Structure analysis Red, Green and Blue demonstrating different clusters. i. Model based origin of accessions with cluster number $3 \mathrm{~K}=3$. Membership coefficients $\left(Q_{s}\right)$ are denoted vertically for each sample ii. Likelihood plots iii. $\Delta \mathrm{K}$ from the structure analysis of the full set of 14 populations. Only the maximum log-likelihood from the 11 iterations runs performed at each $\mathrm{K}$ included in the log-likelihood plots. 
Structure clustering at Ks $=3$ highlighted three distinct groups with the inferred clusters i. 0.369 , ii. 0.304 , iii. 0.327 . The estimated mean value of Ln probability likelihood was found -160.16 with the variance of ln likelihood was 851.5 . In group I the total percentage of genetic structure variation was $28.4 \%$ ( ${ }^{*}$ red lines) in which $46 \%$ belongs to Karnataka followed by few Kerala and Telangana admixtures. In group II, 26.55\% ( ${ }^{\star}$ green lines) and group III, 20.33\% (*blue lines) with $21.46 \%$ of admixtures. Structure analysis revealed that genetic structure of Kerala and Karnataka and Telangana populations were admixtures and classified in three groups Figure 8 and it is varying among the individuals with 25 primers and the structure lines were divided into three groups I, II, III and admixtures.

Table 10. Principal component analysis among different microsatellite markers of selected $S$. album Accessions.

\begin{tabular}{lccc}
\hline PCs & Eigenvalue & Variation\% & Cumulative percentage (\%) \\
\hline PC1 & 3.16 & 7.9 & 7.9 \\
PC2 & 3.01 & 7.5 & 15.4 \\
PC3 & 2.8 & 7.1 & 22.6 \\
PC4 & 2.5 & 6.3 & 28.9 \\
PC5 & 2.4 & 6.2 & 35.1 \\
PC6 & 2.2 & 5.7 & 40.7 \\
PC7 & 2.2 & 5.5 & 46.2 \\
PC8 & 1.9 & 4.9 & 51.1 \\
PC9 & 1.9 & 4.9 & 56.0 \\
PC10 & 1.8 & 4.5 & 60.6 \\
PC11 & 1.6 & 4.2 & 64.8 \\
PC12 & 1.6 & 4.1 & 68.9 \\
PC13 & 1.4 & 3.7 & 72.5 \\
PC14 & 1.4 & 3.6 & 76.1 \\
PC15 & 1.3 & 3.3 & 79.4 \\
PC16 & 1.1 & 2.8 & 82.3 \\
PC17 & 0.98 & 2.5 & 84.7 \\
PC18 & 0.91 & 2.3 & 87.0 \\
PC19 & 0.90 & 2.3 & 89.3 \\
PC20 & 0.87 & 2.2 & 91.5 \\
PC21 & 0.79 & 2.0 & 93.5 \\
PC22 & 0.74 & 1.9 & 95.3 \\
PC23 & 0.66 & 1.7 & 98.0 \\
PC24 & 0.65 & 1.4 & \\
PC25 & 0.544 & & \\
\hline
\end{tabular}

Level of significance ${ }^{*} \mathrm{p}<0.05 ;{ }^{* *} \mathrm{p}<0.01$. 


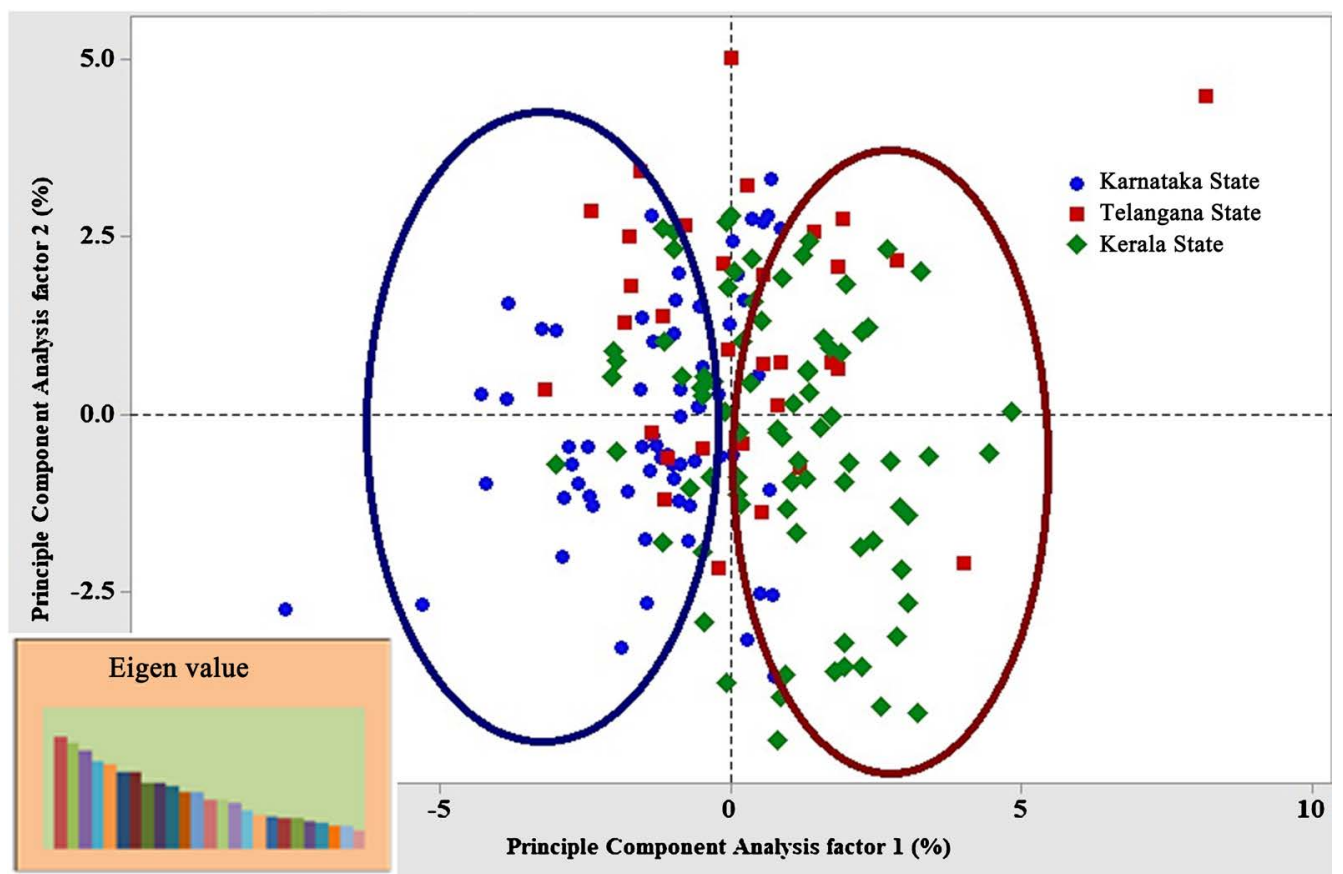

Figure 9. Primary Principle Component analysis (PCA) of genetic distances among the $S$. album accessions from 14 populations (Colored vertical bars in the Eigenvalues histogram.

PCA analysis grouped Sandalwood populations into two mixed groups of Karnataka, Kerala and Telangana populations. PCA showed similar results as for UPGMA dendrogram clustering. A three-dimensional scatter plot based on the first and second principal components of the 177 accessions indicated different levels and directions. So that the degree of relationship between the SSR markers could be discriminated. Eigenvalue of each principal component analysis was greater than 1 (except 9 PCs) showed high variability and performed the importance for the selection of the genotypes. The above results showed the combined variation $82.2 \%$ of these markers. Eigenvalues and variance associated with each principal components gradually decreased and cumulative percentage increased Table 10. The PCA analysis further illustrates the geographical differences between the populations. Analysis revealed that Kerala populations and Telangana populations were more similar than Karnataka and Telangana populations with few admixtures among individuals. Total populations were clustered into 2 discrete groups (I) Karnataka (II) Kerala state and Telangana with the overlapping of few samples of Karnataka, Kerala and Telangana. The PC1 (Component 1) 7.9\% and PC2 (Component 2) 7.5\% of the total variance 81.1 respectively Figure 9.

\section{Discussion}

The main aim of this study was to explore the genetic diversity and determining the genetic structure of $S$. album based on their geographic location and allows the selection of superior genotypes for further genetic improvement in $S$. album. [24] used allozymes to identify the genetic variability in $S$. album that could be 
used for in situ conservation and revealed the high level of heterozygosity with average no of alleles and no of effective alleles $(\mathrm{Na}$ and $\mathrm{Ne}$ ) was (2.174 and 1.602 ) in sandalwood populations in peninsular India. In this research we found high level of polymorphism by using microsatellite markers with average No. of alleles and no of effective alleles per locus ( $\mathrm{Na}$ and $\mathrm{Ne}$ ) was (9.10 and 7.56). In $S$. austrocaledonicum a native species of New Caledonia and Vanuatu genetic diversity study by 8 developed SSR markers, estimated the total number of alleles per locus (Na) was ranged from 3 - 33 [9] while in $S$. album $(\mathrm{Na})$ was ranged from $7.25-8.50$ by these selective markers. These results suggested that $S$. austrocaledonicum was highly polymorphic than $S$. album accessions. High polymorphism was found in $S$. spicatum with the number of alleles per locus ranged from $(2-10)$ and in $S$. album it was ranged from $(9-10)$ with the range of 9.5 . [25] In S. lanceolatum (Northern sandalwood) and S. leptocladum (Southern sandalwood) a native species of Australia characterized eight nuclear microsatellite markers and tested against [9] [10] for amplification. Three microsatellite markers Lanc03, MSaCIR09 and MSaCIRH10 (AM113978 AJ831397 AJ831403) were produced total number of alleles $(\mathrm{Na})$ and expected heterozygosity in $S$. lanceolatum was $\mathrm{Na}(9,16$ and 10$) ; \mathrm{He}(0.37,0.76$ and 0.56$)$ respectively. In $S$. leptocladum $\mathrm{Na}$ (2, 8 and 6); $\mathrm{He}(0.11,0.83$ and 0.61$)$. In our study for above mentioned primers in $S$. album were showing more polymorphic no of alleles, $\mathrm{Na}(13.42,8.500$ and 7.21); Ho (0.890, 0.833 and 0.863). These results indicated that more polymorphism in $S$. album populations than other sandalwood species. In $S$. spicatum the expected heterozygosity (Ho) was ranged from 0.00 0.884 with the mean value 0.756 [12]. Whereas in this study the expected heterozygosity was observed from $(0.657-0.798)$ with the mean value 0.727 in $S$. album in naturally and plantation population growing in Southern India. The above results indicated the similarity of $S$. album and $S$. spicatum due to presence of similar number of alleles and expected heterozygosity. Higher genetic diversity was found in nine Lolium species by using of Thirty-two nuclear SSR markers and the average PIC value 0.83 which revealed the outcrossing species than inbreeding species [26]. In this study the average PIC value 0.87 was obtained for selected markers respectively which also revealed the outcrossing performance of $S$. album. Sandalwood performs largely outcrossing mating and to avoid inbreeding depression they required abundant population size for gene flow. Cluster analysis of the selected sandalwood populations suggested that gene flow and outcrossing opportunities might have been restricted [27] and the above results showed that lowest gene flow was obtained in LC126834 primer and highest were found in LC126839 with an average 5.29. The genetic differentiation among population is low when the coefficient of degree of differentiation $\left(\mathrm{F}_{\mathrm{ST}}\right)$ is less than 0.25 [28]. The $\mathrm{F}$ statistics results of the present study showed that the genetic differentiation among 14 sandalwood (natural and plantation) populations was relatively low $\left(\mathrm{F}_{\mathrm{ST}} \max -0.104\right.$ and $\left.\mathrm{F}_{\mathrm{ST}}-0.118, \mathrm{P}>0.001\right)$ and the genetic variation was mostly found in within populations and within indi- 
viduals. The low degree of genetic variability within sandalwood populations might be due to the fragmentation of a previously large origin population, discrimination of attributions due to random genetic drift and minimum amount of gene flow between the populations [29]. The average of $\mathrm{F}_{\mathrm{ST}}$ was 0.003 that denoted the $3 \%$ of the genetic variation existed among the populations. The average of Nm was $5.32>1$ implied that the high rate of gene flow occurred within populations than among the populations. Comparison of the UPGMA dendrogram with the two-dimensional principal component analysis plot provided a greater understanding of the complexity of relationship of the selected microsatellite markers, $S$. album accessions and the germplasm origin. This study revealed that gene flow was high in natural populations as compared to plantation populations. The nearest genetic distance was found in between Telangana and Kerala. The longest genetic distance was found in between Telangana state and Karnataka populations that indicated that the populations of Telangana state mostly belongs to Kerala populations rather than Karnataka populations. In the present study, the gene flow of $S$. album populations was relatively high in Telangana state as compared to Kerala and Karnataka. In $S$. album isozyme study indicated a high level of gene flow among the populations than across the geographical regions [3]. The gene flow within S. album populations in selected states of Southern India was relatively high in Telangana state as compared to Kerala and Karnataka state (mean 5.295). Among the 25 SSR markers LC126834 (O. lanceolata) showed highest polymorphism. A Marker with high He and PIC value is useful for genetic diversity and distinguish the genotypes belongs to different populations. [30]. The genetic transferability of the SSR markers in genus S. album is highly conserved [31]. Though in this study we found that $84 \%$ transferability of $O$. lanceolata, $81 \%$ of $S$. spicatum, $72 \% S$. insulare and $78 \% S$. austrocaledonicum in $S$. album that is quite higher than the other genus transferability. Cross species transferability of SSR indicated the conservation of primer and compared to less reproducible marker [32]. In this research we found that the high polymorphism in $S$. album by these selected SSR markers. This result indicated that genetic structure of $S$. album mostly similar to $S$. spicatum and $O$. lanceolata.

\section{Conclusion}

The present study identified the high profile of genetic diversity population of Sandalwood such as Kodada Telangana, Suryapet Telangana, IWST Bangalore, Dharwad and Hassan Karnataka in southern India. Identification of these hot spot populations would be helpful in collecting and maintaining germplasm for sandalwood. These findings of the present study can have important implications for the ex-situ, in-situ conservation, selection for genetic improvement program (Micropropagation, cloning, tissue culture). It was concluded that Sandalwood populations with high genetic diversity should be given preferential for developing in situ conservation strategies. Additionally, these markers would 
be a useful tool for investigating genetic diversity, genetic structure of other regions natural and plantation populations of $S$. album or other sandalwood species.

\section{Acknowledgements}

Authors are thankful to the Director, IWST, Group Co-ordinator Research, Head-Genetics and Tree Improvement Division, Molecular biology lab members in Institute of Wood Science and Technology. The authors also wish to thank Hassan DFO, Dharwad DFO, Director, Institute of Forest Diversity Hyderabad, Suryapet Khammam Telangana state farmers, and their assistance on field trips and sample collection.

\section{Author Contributions}

All author equally contributed.

\section{Author Statement}

All authors read, reviewed, agree and approved the final manuscript.

\section{Conflicts of Interest}

None declared.

\section{References}

[1] IUCN (2007) IUCN Red List of Threatened Species. https://www.iucnredlist.org/

[2] Kumarvelu, G., Bharathi, R.K., Jainaldeen, A. and Balraj, V.C. (2007) Resurrection of the Rare Aromatic Santalum album Population in Tamil Nadu, India. Proceedings of National Seminar, 23-31.

[3] Rao, N.M., Ravikanth, G., Ganeshaiah, K.N., Rathore, T.S. and Shaanker, R.U. (2007) Assessing Threats and Identifying the Ecological Niche of Sandal Resoures to Identify "Hot-Spots" for in Situ Conservation in Southern India. Sandal Proceedings of National Seminar, 23-31.

[4] Jones, C.G., Plummer, J.A. and Barbour, L. (2007) Non-Destructive Sampling of Indian Sandalwood (Santalum album L.) for Oil Content and Composition. Journal of Essential Oil Research, 19, 157-164. https://doi.org/10.1080/10412905.2007.9699250

[5] Azeez, S.A., Nelson, R., Prasadbabu, A. and Rao, M.S. (2009) Genetic Diversity of Santalum album Using Random Amplified Polymorphic DNAs. African Journal of Biotechnology, 8, 2943-2947.

[6] Murray, M.G. and Thompson, W.F. (1980) Rapid Isolation of High Molecular Weight Plant DNA. Nucleic Acid Research, 8, 4321-4325. https://doi.org/10.1093/nar/8.19.4321

[7] Fatima, T., Srivastava, A., Hanur, V.S. and Rao, S.M. (2018) An Effective Wood DNA Extraction Protocol for Three Economic Important Timber Species of India. American Journal of Plant Sciences, 9, 139-149. https://doi.org/10.4236/ajps.2018.92012

[8] Otieno, O.J., Omondi, S.F., Perry, A., Odee, W.D., Makatiani, E.T., Kiplagat, O. and Cavers, S. (2016) Development and Characterization of Microsatellite Markers for 
Osyris lanceolata Hochst. \& Steud., an Endangered African Sandalwood Tree Species. Tropical Plant Research (An International Journal), 701-703. http://www.tropicalplantresearch.com/archives/2016/vol3issue3/092.pdf

[9] Bottin, L., Vaillant, A., Sire, P., Cardi, C. and Bouvet, M. (2005) Isolation and Characterization of Microsatellite Loci in Santalum austrocaledonicum, Santalaceae. Molecular Ecology Notes, 5, 800-802. https://doi.org/10.1111/j.1471-8286.2005.01067.x

[10] Emeline, L., Alexandre, V., Francoist, B.J. and Marc, B.J. (2006) Isolation and Characterization of Microsatellite Loci in Santalum insulare, Santalaceae. Molecular Ecology Notes, 653-655. https://doi.org/10.1111/j.1471-8286.2006.01279.x

[11] Millar, M.A., Byrne, M. and Barbour, E. (2012) Characterization of Eleven Polymorphic Microsatellite DNA Markers for Australian Sandalwood (Santalum spicatum) (R. Br.) A. D.C. (Santalaceae). Conservation Genetics, 4, 51-53.

https://doi.org/10.1007/s12686-011-9473-9

[12] Williams, J.G.K., Kubelik, A.R., Livak, K.J., Rafalski, J.A. and Tingey, S.V. (1990) DNA Polymorphisms Amplifies by Arbitrary Primers Are Useful as Genetic Markers. Nucleic Acid Research, 313, 101-105. https://www.ncbi.nlm.nih.gov/pubmed/1979162.

[13] Ipek, A., Barut, E., Gulen, H. and Ipek, M. (2012) Assessment of Inter and Intra Cultivar Variations in Olive Using SSR Markers. Scientia Agricola, 69, 327-335. https://doi.org/10.1590/S0103-90162012000500007

[14] Peakall, R. and Smouse, P.E. (2012) GENALEX 6.5: Genetic Analysis in Excel. Genetic Analysis in Excel. Population Genetic Software for Teaching and ResearchAn Update. Bioinformatics (Oxford, England), 28, 2537-2539. https://doi.org/10.1093/bioinformatics/bts460

[15] Peakall, R. and Smouse, P.E. (2006) GENALEX 6: Genetic Analysis in Excel. Population Genetic Software for Teaching and Research. Molecular Ecology Notes, 6, 288-295. https://doi.org/10.1111/j.1471-8286.2005.01155.x

[16] Yeh, F.C. and Yang, R. (1999) Microsoft Window-Based Freeware for Population Genetic Analysis (POPGENE Ver. 1.31). University of Alberta, Alberta.

[17] Pritchard, J.K., Stephens, M. and Donelly, P. (2000) Inference of Population Structure Using Multilocus Genotype Data. Genetics, 155, 945-959.

[18] Earl, D.A. and Vonholt, B.M. (2012) STRUCTURE HARVESTER: A Website and Program for Visualizing STRUCTURE Output and Implementing the Evanno Method. Consevation Genetic Resources, 4, 359-361. https://doi.org/10.1007/s12686-011-9548-7

[19] Rosenberg, N.A., Burke, T., Elo, K., Feldman, M.W. and Freidlin, P.J. (2001) Empirical Evaluation of Genetic Clustering Methods Using Multilocus Genotypes from 20 Chicken Breeds. Genetics, 159, 699-713.

[20] Evanno, G., Regnaut, S. and Goudet, J. (2005) Detection the Number of Clusters of Individuals Using the Software STRUCTURE: A Simulation Study. Molecular Ecology, 14, 2611-2620. https://doi.org/10.1111/j.1365-294X.2005.02553.x

[21] Ma, M., Lie, E., Meng, H., Wang, T., Xie, L., Shen, D., Zhou, X. and Lu, B. (2017) Cluster and Principal Component Analysis Based on SSR Markers of Amomum Tsao-Ko in Jinping Country of Yunnan Province. AIP Conference Proceedings, 1864, Article ID: 020070.

[22] Nie, M. (1973) Molecular Evolution in Search of Itself. Molecular Evolutionary Genetics, Cell, 51, 343-344.

[23] Nei, M. (1978) Estimation of Average Heterozygosity and Genetic Distance from a 
Small Number of Individuals. Genetics, 89, 583-590.

[24] Rao, N.M., Ganeshaiah, K.N. and Shaankar, R.U. (2007) Assessing Threats and Mapping Sandal Resources to Identify Genetic "Hot-Spot" for in Situ Conservation in Peninsular India. Conservation Genetics, 8, 925-935.

https://doi.org/10.1007/s10592-006-9247-1

[25] Jones, B.L., Waycott, M., Heather, L.A., Calladine, R.A. and Page, T. (2010). Isolation and Characterization of Microsatellite Loci in Santalum lanceolatum and Santalum leptocladum (Santalaceae). American Journal of Botany, 97, e97-e98. https://doi.org/10.3732/ajb.1000213

[26] Guan, X., Yuyama, N., Stewart, A., Ding, C., Xu, N., Kiyoshi, T. and Cai, H. (2017) Genetic Diversity and Structure of Lolium Species Surveyed on Nuclaer Simple Sequence Repeat and Cytoplasmic Markers. Frontiers in Plant Sciences, 8, 584. https://doi.org/10.3389/fpls.2017.00584

[27] Ratnaningrum, Y.W.N., Indrioko, S., Faridah, E. and Syahbudin, A. (2017) Gene Flow and Selection Evidence of Sandalwood (Santalum album) under Various Population Structures in Gunung Sewu (Java, Indonesia), and Its Effects on Genetic Differentiation. Biodiversitas, 18, 1493-1505.

[28] Wright, S. (1965). The Interpretation of Population Structure by F-Statistics with Special Regard to Systems of Mating. Evolution, 19, 395-420. https://doi.org/10.1111/j.1558-5646.1965.tb01731.x

[29] Suma, T.B. and Balasundaran, B. (2003) Isozyme Variation in Five Provenances of Santalum album in India. Australian Journal of Botany, 51, 243-249. https://doi.org/10.1071/BT02094

[30] Mohammad, N., Mahesh, S., Kumar, P. and Ansari, S.A. (2012) Genotyping of Santalum album L. Accessions through Cross-Species Transferability of SSR Markers of Santalum austrocaledonicum and Santalum insulare. Sandalwood Research Newsletter, $1-4$.

[31] Byrne, M., Marquez-Garcia, M.I., Uren, T., Smith, D.S. and Moran, G.G. (1996) Conservation and Genetic Diversity of Microsatellite Loci in the Genus Eucalyptus. Australian Journal of Botany, 44, 331-341. https://doi.org/10.1071/BT9960331

[32] Patel, D.M., Fougat, R.S., Sakure, A.A., Kumar, S., Kumar, M. and Mistry, J.G. (2016) Detection of Genetic Variation in Sandalwood Using Various DNA Markers. 3 Biotech, 6, 55. https://doi.org/10.1007/s13205-016-0391-0
Abbreviations
Ho: Observed heterozygosity
He: expected heterozygosity
$\mathrm{Na}$ : Number of alleles
$\mathrm{Ne}$ : Effective number of alleles
$\mathrm{Nm}$ : Number of migrants (Gene flow)
PIC: Polymorphic information content
I: Shannon information index
F: Inbreeding coefficient 